\title{
Invertebrate Response to Changes in Streamilow Hydraulics in Two Urban Areas in the United States
}

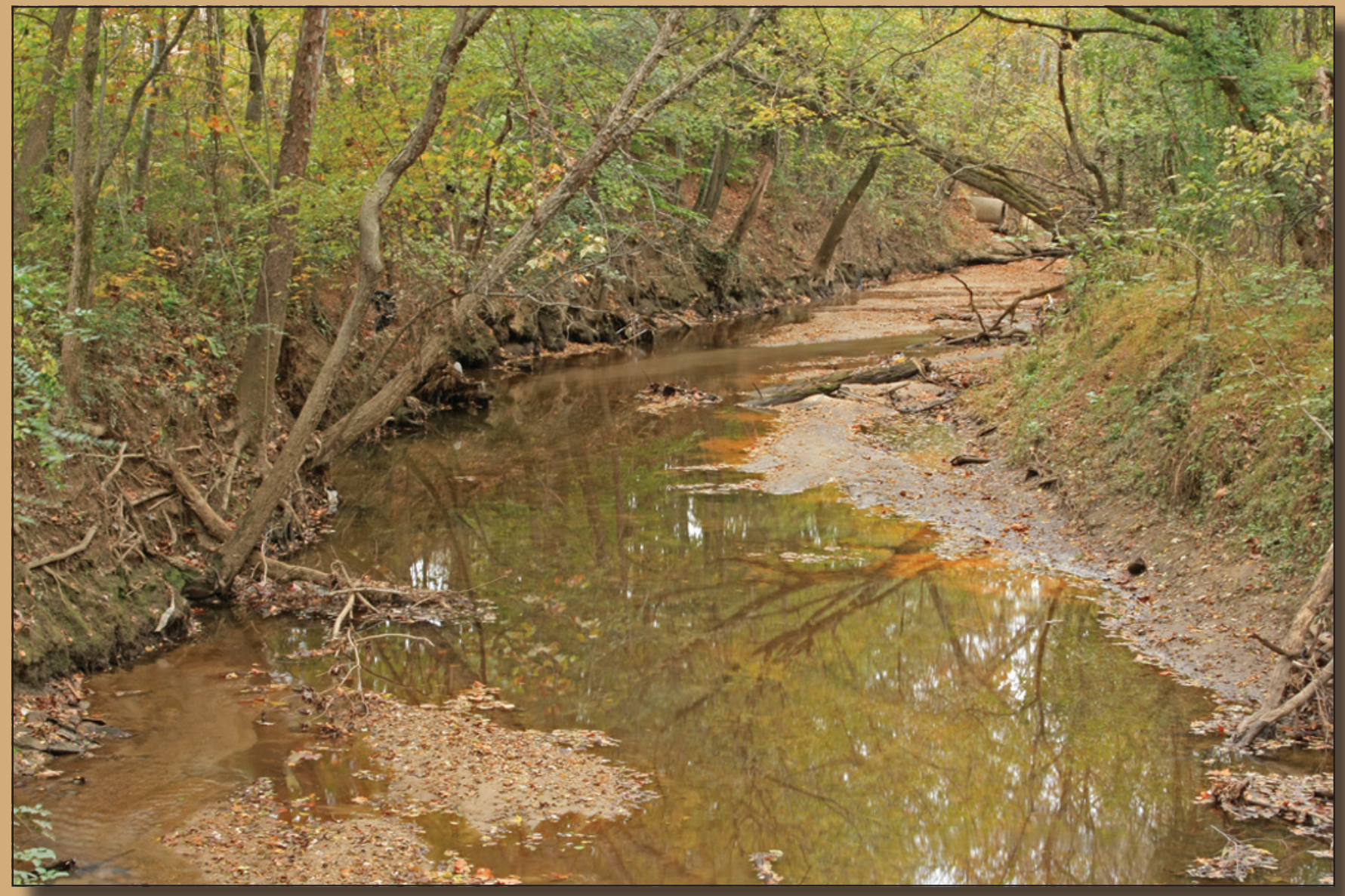

Scientific Investigations Report 2012-5035 
Cover photographs. Pigeon House Branch, above confluence with Crabtree Creek, Raleigh, Wake County, North Carolina. Photograph by Alan Cressler, USGS. 


\section{Invertebrate Response to Changes in Streamflow Hydraulics in Two Urban Areas in the United States}

By Rodney R. Knight and Thomas F. Cuffney

National Water-Quality Assessment Program

Scientific Investigations Report 2012-5035 


\section{U.S. Department of the Interior \\ KEN SALAZAR, Secretary \\ U.S. Geological Survey \\ Marcia K. McNutt, Director}

\section{U.S. Geological Survey, Reston, Virginia: 2012}

For more information on the USGS — the Federal source for science about the Earth, its natural and living resources, natural hazards, and the environment, visit http://www.usgs.gov or call 1-888-ASK-USGS.

For an overview of USGS information products, including maps, imagery, and publications, visit http://www.usgs.gov/pubprod

To order this and other USGS information products, visit http://store.usgs.gov

Any use of trade, product, or firm names is for descriptive purposes only and does not imply endorsement by the U.S. Government.

Although this report is in the public domain, permission must be secured from the individual copyright owners to reproduce any copyrighted materials contained within this report.

Suggested citation:

Knight, R.R., and Cuffney, T.F., 2012, Invertebrate response to changes in streamflow hydraulics in two urban areas in the United States: U.S. Geological Survey Scientific Investigations Report 2012-5035, 19 p. 


\section{Contents}

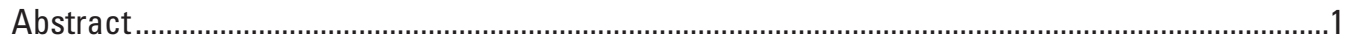

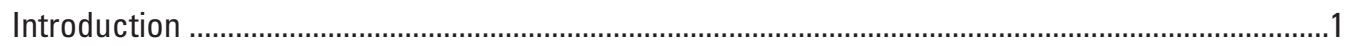

Site Selection and Description of Study Areas ..........................................................................2

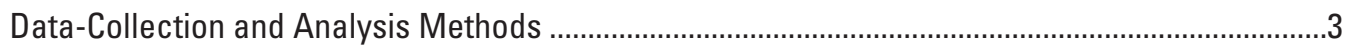

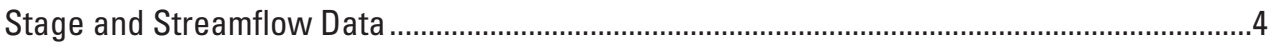

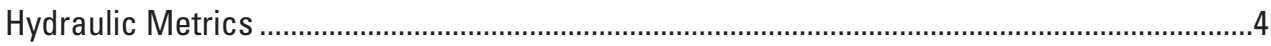

Invertebrate Data and Metrics ................................................................................................

Invertebrate Responses to Urbanization and Hydraulics .......................................................6

Hydraulic Metrics and Urban Intensity ...........................................................................................6

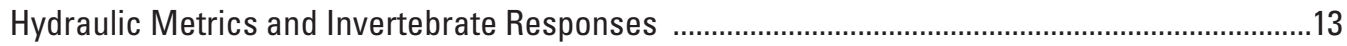

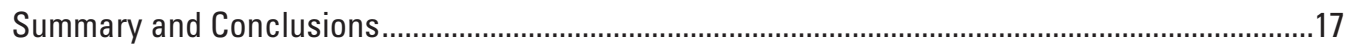

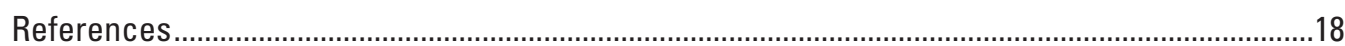

\section{Figures}

1. Map showing locations of the nine metropolitan study areas across

2. Charts showing annual pattern of mean monthly precipitation and temperature in Milwaukee-Green Bay and Raleigh

3. Charts showing annual patterns in hydraulic metrics representing bed disturbance for high and low urban-intensity sites in the MilwaukeeGreen Bay and Raleigh metropolitan areas

4. Charts showing annual patterns in hydraulic metrics representing flow suitability for high and low urban-intensity sites in the MilwaukeeGreen Bay and Raleigh metropolitan areas

5. Charts showing annual patterns in hydraulic metrics representing bed exposure in high and low urban-intensity sites in the MilwaukeeGreen Bay and Raleigh metropolitan areas

6. Charts showing hydraulic metrics for low and high urban-intensity sites in Milwaukee-Green Bay and Raleigh based on annual statistics

7. Chart showing frequency and duration of streamflow based on hourly stage data in Milwaukee-Green Bay and Raleigh based on annual statistics 


\section{Tables}

1. Major environmental characteristics of the Milwaukee-Green Bay,

Wisconsin, and Raleigh, North Carolina, metropolitan areas..

2. Description of hydraulic metrics modeled from measurements of stream stage and channel geometry

3. Definitions and sources of information for the invertebrate richness and abundance metrics used in this study.

4. Hydraulic metrics that were significantly correlated with urban intensity in Milwaukee-Green Bay and Raleigh and the number of invertebrate metrics that were significantly correlated with each of these hydraulic metrics.

5. Number and percentage of statistically significant correlations between hydraulic and invertebrate metrics in MilwaukeeGreen Bay, Raleigh, and both RAL and MGB.

6. Explanatory variables (hydraulic metrics and urban intensity) associated with invertebrate richness metrics based on Spearman rank correlation and CART and BEST analyses for Milwaukee-Green Bay and Raleigh.

7. Explanatory variables (hydraulic metrics and urban intensity) associated with invertebrate abundance metrics based on Spearman rank correlation and CART and BEST analyses in Milwaukee-Green Bay and Raleigh 


\section{Conversion Factors}

SI to Inch/Pound

\begin{tabular}{|c|c|c|}
\hline Multiply & By & To obtain \\
\hline \multicolumn{3}{|c|}{ Length } \\
\hline centimeter $(\mathrm{cm})$ & 0.3937 & inch (in.) \\
\hline meter $(\mathrm{m})$ & 3.281 & foot $(\mathrm{ft})$ \\
\hline kilometer (km) & 0.6214 & mile (mi) \\
\hline kilometer (km) & 0.5400 & mile, nautical (nmi) \\
\hline meter (m) & 1.094 & yard (yd) \\
\hline \multicolumn{3}{|c|}{ Area } \\
\hline square meter $\left(\mathrm{m}^{2}\right)$ & 0.0002471 & acre \\
\hline square kilometer $\left(\mathrm{km}^{2}\right)$ & 247.1 & acre \\
\hline square centimeter $\left(\mathrm{cm}^{2}\right)$ & 0.001076 & square foot $\left(\mathrm{ft}^{2}\right)$ \\
\hline square meter $\left(\mathrm{m}^{2}\right)$ & 10.76 & square foot $\left(\mathrm{ft}^{2}\right)$ \\
\hline square centimeter $\left(\mathrm{cm}^{2}\right)$ & 0.1550 & square inch $\left(\mathrm{ft}^{2}\right)$ \\
\hline square kilometer $\left(\mathrm{km}^{2}\right)$ & 0.3861 & square mile $\left(\mathrm{mi}^{2}\right)$ \\
\hline \multicolumn{3}{|c|}{ Volume } \\
\hline cubic meter $\left(\mathrm{m}^{3}\right)$ & 6.290 & barrel (petroleum, 1 barrel $=42$ gal) \\
\hline cubic meter $\left(\mathrm{m}^{3}\right)$ & 264.2 & gallon (gal) \\
\hline cubic meter $\left(\mathrm{m}^{3}\right)$ & 0.0002642 & million gallons (Mgal) \\
\hline cubic meter $\left(\mathrm{m}^{3}\right)$ & 35.31 & cubic foot $\left(\mathrm{ft}^{3}\right)$ \\
\hline cubic meter $\left(\mathrm{m}^{3}\right)$ & 1.308 & cubic yard $\left(\mathrm{yd}^{3}\right)$ \\
\hline cubic meter $\left(\mathrm{m}^{3}\right)$ & 0.0008107 & acre-foot (acre-ft) \\
\hline \multicolumn{3}{|c|}{ Flow rate } \\
\hline cubic meter per second $\left(\mathrm{m}^{3} / \mathrm{s}\right)$ & 70.07 & acre-foot per day (acre-ft/d) \\
\hline cubic meter per second $\left(\mathrm{m}^{3} / \mathrm{s}\right)$ & 35.31 & cubic foot per second $\left(\mathrm{ft}^{3} / \mathrm{s}\right)$ \\
\hline cubic meter per second $\left(\mathrm{m}^{3} / \mathrm{s}\right)$ & 22.83 & million gallons per day (Mgal/d) \\
\hline
\end{tabular}

Temperature in degrees Celsius $\left({ }^{\circ} \mathrm{C}\right)$ may be converted to degrees Fahrenheit $\left({ }^{\circ} \mathrm{F}\right)$ as follows:

${ }^{\circ} \mathrm{F}=\left(1.8 x^{\circ} \mathrm{C}\right)+32$

Temperature in degrees Fahrenheit $\left({ }^{\circ} \mathrm{F}\right)$ may be converted to degrees Celsius $\left({ }^{\circ} \mathrm{C}\right)$ as follows:

${ }^{\circ} \mathrm{C}=\left({ }^{\circ} \mathrm{F}-32\right) / 1.8$ 


\title{
Invertebrate Response to Changes in Streamflow Hydraulics in Two Urban Areas in the United States
}

\author{
By Rodney R. Knight and Thomas F. Cuffney
}

\section{Abstract}

Stream hydrology is foundational to aquatic ecosystems and has been shown to be a structuring element for fish and invertebrates. The relations among urbanization, hydraulics, and invertebrate communities were investigated by the U.S. Geological Survey, National Water-Quality Assessment Program by using measures of stream hydraulics in two areas of the United States. Specifically, the hypothesis that the effects of urbanization on streamflow and aquatic biota are transferable across geographic regions was tested. Data from sites in Raleigh, North Carolina, and Milwaukee-Green Bay, Wisconsin, were compared and indicate that increasing urbanization has an effect on hydraulic characteristics (Reynolds number, shear stress, and stream power for example) in each metropoli$\tan$ area, though limited commonality of significant correlations was noted between areas. Correspondence of significant correlations between invertebrate and hydraulic metrics between study areas also was limited. The links between urbanization, hydraulics, and invertebrates could be seen only in the Raleigh data. Connections among these three elements in the Milwaukee-Green Bay data were not clear and likely were obscured by antecedent land cover. Observed biotic differences due to hydrology and urbanization characteristics are not similar between geographic regions.

\section{Introduction}

Urbanization has been shown to adversely affect stream biota and ecological function, including degradation of invertebrate assemblages (Booth and Jackson, 1997; Paul and Meyer, 2001; Konrad and Booth, 2002; Roy and others, 2003). Alteration of the natural flow regime is one mechanism by which urbanization degrades benthic invertebrate assemblages. Increases in impervious surfaces (roads and buildings), development of riparian and flood-plain areas, construction of water-distribution systems (for distribution of drinking water, wastewater, and stormwater), and creation of flood-control structures (dams, bank stabilization, and channelization) all disrupt normal patterns of flow. Typically, these changes act to move water more rapidly to or through the stream, resulting in flow regimes that are flashier, that is, having more frequent high flows and lower and longer duration low flows than the natural flow regimes. These changes affect the macroinvertebrate communities by altering crucial habitat characteristics, such as water depth, velocity, substrate, and amount and stability of habitat. These changes can lead to loss of biota because flow conditions no longer support the environmental requirements of the biota, such as filter-feeding organisms, or do not exist long enough for the organisms to complete their lifecycles.

Alteration of flow typically has been characterized by using measures of streamflow (Richter and others, 1996; Clausen and Biggs, 2000; Olden and Poff, 2003) or stream stage as an indicator of discharge (Giddings and others, 2009). Characterizing flow in this manner provides only an indirect association of flow with the mechanisms that directly affect biota, such as shear stress, velocity, and available habitat. Steuer and others (2009) developed an alternative method of estimating hydraulic characteristics that directly affect biota. This method involves simulating hydraulic conditions through time based on continuous stream-stage records coupled with a few measurements of streamflow, channel gradient, and morphology. This modeling approach provides direct estimates of hydraulic (for example, depth and velocity) and derivative variables (for example, shear stress, Reynolds number, and Froude number) at smaller, more biologically relevant spatial and temporal scales than is possible with hydrograph metrics or in-stream, point-in-time hydraulic measurements. Steuer and others (2009) used this modeling approach to investigate relations among urbanization, stream hydraulics, and aquatic biota in 30 basins that represented a gradient of urbanization in the Milwaukee-Green Bay (MGB), Wisconsin, metropoli$\tan$ area. Their results indicate positive correlations between basin urbanization and low shear stress, Reynolds number, and fraction of bed exposed, and measureable biologic linkages between hydraulic metrics and ecological conditions (for example, richness of filter-feeding invertebrates increased with minimum shear stress within a reach). Other associations between hydraulic and biological metrics relate to the time period (annual, seasonal, or monthly) over which the metric was averaged. 
MGB was one of nine metropolitan areas that were studied for the effects of ecosystem change resulting from urbanization as part of the U.S. Geological Survey (USGS) National Water-Quality Assessment Program (fig. 1). Analyses of responses of invertebrate metrics to urbanization in these nine metropolitan areas revealed that benthic macroinvertebrates had the strongest and most consistent responses to urbanization (Brown and others, 2009) and that responses were strongest in metropolitan areas where forest or shrub lands were being converted to urban areas (Cuffney and others, 2010). Responses in metropolitan areas where agricultural lands were being converted to urban areas showed much weaker or non-significant responses to urbanization because the streams were highly disturbed prior to urbanization. The influence of agriculture coupled with the responses to urbanization makes it difficult to generalize the MGB results to other metropolitan areas, particularly those where forest lands are being converted to urban areas.

Stream hydrology is known to be important in structuring invertebrate assemblages (Quinn and Hickey, 1994; Robertson and others, 1997), and changes in hydrology associated with urbanization have been implicated as causal mechanisms in the degradation of streams (Paul and Meyer, 2001; Konrad and Booth, 2002; Walsh and others, 2005). However, the links among urbanization, hydrology, and invertebrate responses have not been well studied. Steuer and others (2009) linked differences in hydraulic metrics to differences in invertebrate, fish, and algal assemblages in MGB across a gradient of urbanization. This study extends their work by comparing the relations among hydraulics, urbanization, and invertebrate responses in two urban areas that differ in regional characteristics, such as climate and topography, and the type of land cover that is being converted to urban land.
In order to understand the effects of antecedent land use in combination with responses to urbanization, previous work by Steuer and others (2009) (MGB) was expanded and, using their methods, contrasted with results obtained for a metropolitan area in which forest land is being converted to urban land [Raleigh (RAL), North Carolina]. The purposes of this study are to (1) evaluate the response of the hydraulic variables to urbanization, (2) assess the strength of correlations between hydraulic variables and benthic macroinvertebrate metrics, and (3) contrast results between the two metropolitan areas (that is, effects of antecedent land cover). Hydraulic characteristics and invertebrate data from streams representing a gradient of urbanization in RAL and MGB were used in this study.

\section{Site Selection and Description of Study Areas}

Sites used in this investigation were part of a study that compared streams across gradients of urbanization in nine major metropolitan areas across the United States (Brown and others, 2009; fig. 1). Sites were selected to minimize natural variations in the physical settings and local site conditions across basins within a metropolitan area (Tate and others, 2005; Cuffney and others, 2010) while maximizing the range of urban conditions in the basins. Basin characteristics used in the analyses included ecoregions, soils, slope, drainage area, land use, climate, urban intensity, infrastructure, and population statistics, all of which were derived by using nationally available geographic information system (GIS) data (Falcone and others, 2007). Urban intensity was characterized by using a multimetric urban-intensity index (metropolitan area national urban-intensity index, MA-NUII; Cuffney and Falcone, 2008)

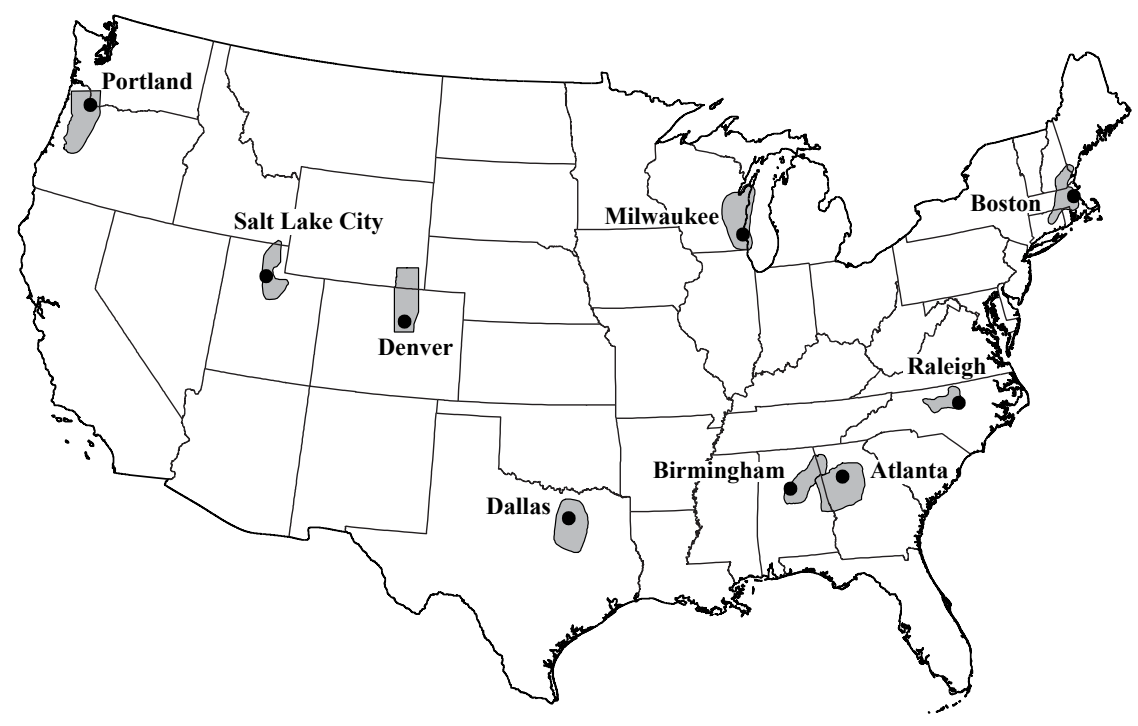

Figure 1. Locations of the nine metropolitan study areas across the United States. 
that combined housing density, percentage of developed land, and road density. Thirty study basins $\left(2^{\text {nd }}-3^{\text {rd }}\right.$-order streams $)$ were selected in each metropolitan area to represent a gradient of urbanization as defined by MA-NUII.

The MGB basins were selected from areas with claydominated surficial deposits in the Southeastern Wisconsin Till Plains ecoregion (Omernik, 2000). Dairy, livestock farming, and associated corn and soybean production represent the current non-urban land uses, though pre-settlement land cover in this area consisted of a mixture of hardwood forests, oak savannahs, and tall grass prairies. Streams in MGB are mostly run habitat, which drain from gently sloped watersheds (1.3-3.3 percent, 2.25 percent mean), and streambed substrate ranges from silt to cobbles (Giddings and others, 2009). Basin sizes vary from 11 to 119 square kilometers $\left(\mathrm{km}^{2}\right.$; Giddings and others, 2009). The majority of the urban development in MGB involves the conversion of agricultural lands.

In contrast, the RAL study sites are located in the Piedmont ecoregion (Omernik, 2000). Soils are primarily silt and clay. Urban development primarily involves conversion of forests (antecedent land cover, southern hardwoods, and pine) that have been reestablished on moderate to severely eroded agricultural lands (Trimble, 1974). Streams in the RAL study area have low to moderate basin slope (2.9-8.8 percent, 5.4 percent mean; table 1 ), which are one to three times greater than the gradients for MGB streams; RAL basin sizes vary from 3 to 62 square kilometers $\left(\mathrm{km}^{2}\right)$ (Giddings and others, 2009). Streambeds are typically gravel and cobble substrate, and habitat is riffle/run.
The MGB and RAL study areas differ substantially in climate. Mean annual air temperatures at the MGB sites vary from 7 to 9 degrees Celsius $\left({ }^{\circ} \mathrm{C}\right)$ and are considered temperate continental. Mean annual precipitation at MGB sites ranges from 79 to 90 centimeters $(\mathrm{cm})$ and primarily occurs between May and September (Daymet, 2005; Falcone and others, 2007). The highest streamflows in MGB usually occur during spring as a result of snowmelt or a combination of rain and snow. The climate in RAL is warm and humid, with mean annual air temperature of $14.9^{\circ} \mathrm{C}$ and mean annual precipitation of $119.2 \mathrm{~cm}$ (table 1; Daymet, 2005; Falcone and others, 2007). Rainfall is distributed relatively evenly throughout the year, with slightly more occurring in July and August and slightly less in October and December (fig. 2). Streamflow, however, typically is highest during the winter when deciduous vegetation is dormant and lowest in late summer as a result of high evapotranspiration.

\section{Data-Collection and Analysis Methods}

Data collection and analysis methods generally follow those outlined in Steuer and others (2009). Continuous stage and discrete streamflow observations were made at all sites in addition to each site being sampled for invertebrate abundance and richness (Steuer and others, 2009). Additionally, detailed habitat observations were made for an extended reach at each site. Water stage, streamflow, and habitat data were combined

Table 1. Major environmental characteristics of the Milwaukee-Green Bay (MGB), Wisconsin, and Raleigh (RAL), North Carolina, metropolitan areas (Falcone and others, 2007).

$\left[{ }^{\circ} \mathrm{C}\right.$, degree Celsius; cm, centimeter; $\mathrm{m}$, meter; $\%$, percent; Antecedent agriculture is the percentage of basin area in row crop and grasslands for sites with low urban intensity (MA-NUI $\leq 10)$; km, kilometer; $\mathrm{km}^{2}$, square kilometers]

\begin{tabular}{lcc}
\hline \multicolumn{1}{c}{ Environmental characteristic } & MGB & RAL \\
\hline Predominant ecoregion & $\begin{array}{c}\text { Southeastern Wisconsin } \\
\text { Till Plains }\end{array}$ & Piedmont \\
Natural vegetation & Forest & Forest \\
Mean annual air temperature $\left({ }^{\circ} \mathrm{C}\right)$ & 7.6 & 14.9 \\
Mean annual precipitation $(\mathrm{cm})$ & 85.5 & 119.2 \\
Gradient (elevation range, $\mathrm{m})$ & 64.0 & 83.0 \\
Mean basin elevation $(\mathrm{m})$ & 236.0 & 180.0 \\
Mean basin slope $(\%)$ & 2.2 & 5.4 \\
Antecedent agriculture $(\%)$ & 79.3 & 24.4 \\
Developed land $(\%)$ & $3.23-99.1$ & $3.01-98.4$ \\
Road density (km of road/ km $\left.{ }^{2}\right)$ & $1.28-10.4$ & $1.03-11.5$ \\
Housing density (housing units/ & $4.45-985$ & $6.70-668$ \\
$\mathrm{~km})^{\mathrm{a}}$ & & \\
\hline
\end{tabular}

a Based on year 2000 U.S. Census block data 

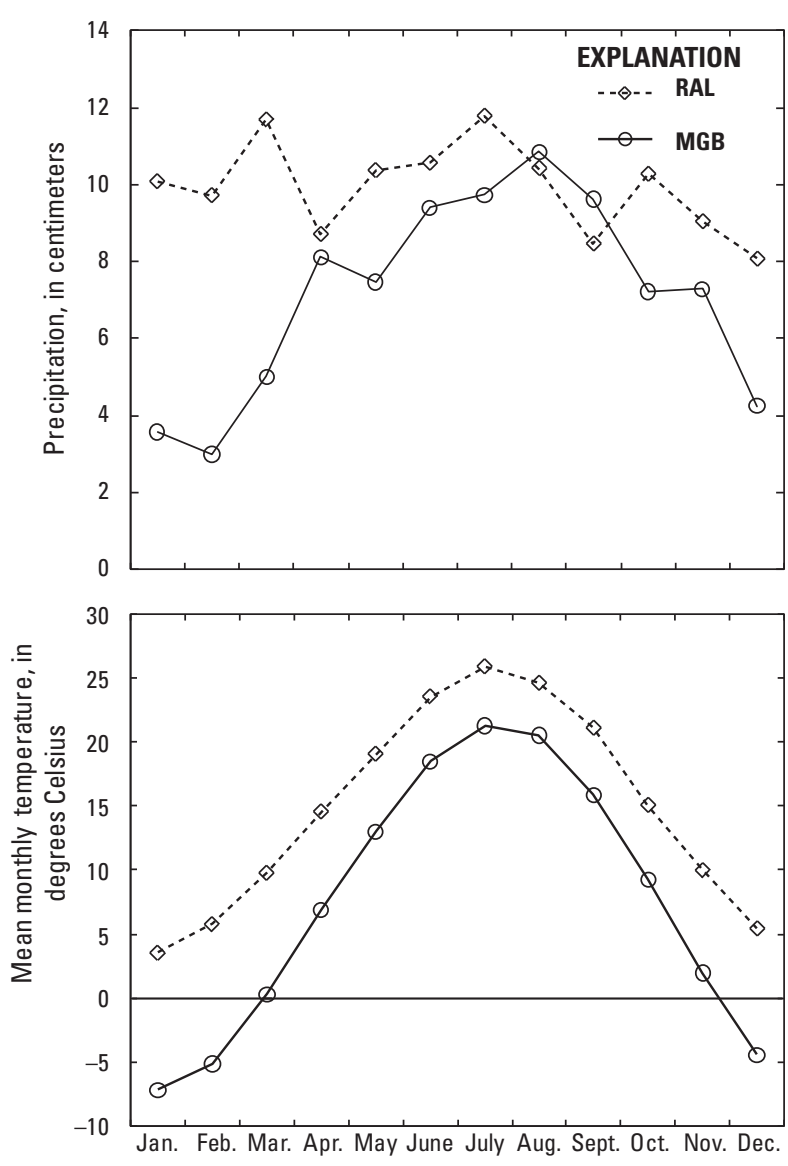

Figure 2. Annual pattern of mean monthly precipitation and temperature in MilwaukeeGreen Bay (MGB) and Raleigh (RAL).

to provide estimates of numerous hydraulic characteristics throughout the reach at each site. Information describing all data collection and analysis techniques are included below.

\section{Stage and Streamflow Data}

Study sites were instrumented with continuous stage sensors for approximately 12 months. Data from RAL sites were collected between October 2002 and November 2003, and data from MGB sites were collected between October 2003 and September 2004. Unvented stage sensors with a range of 0 to 30 meters $(\mathrm{m} ; \pm 3.6 \mathrm{~cm})$ were used for recording hourly stage readings. Stage values were corrected for barometric pressure by using either nearby airport barometric pressure readings or data from a continuous barometric pressure logger deployed in the area. Instrument drift was detected and corrected by periodically comparing the transducer reading to stage measured at a fixed external point. Stage sensors were removed at 16 MGB sites during winter months (December 8 through March 16) to prevent ice damage. Discharge measurements were made at each site to associate stage with discharge. Hourly stage data for RAL were converted to hourly streamflow using a stage-discharge relation that was developed by using a combination of site-specific discharge measurements and steady-flow models following the methodology of Steuer and others (2009). Hourly streamflow data were averaged for each day to calculate daily mean streamflow data for all MGB and RAL sites. Missing hourly streamflow data were not estimated, which resulted in missing daily mean streamflow values. Daily mean streamflow data that were used for MGB sites in this analysis were the same as those used by Steuer and others (2009). Missing daily mean streamflow values for the RAL sites were estimated by using maintenance of variance extension (MOVE.1, Hirsch, 1982). Analyses presented here are based on daily mean streamflow data.

\section{Hydraulic Metrics}

Direct hydraulic variables (depth, velocity, wetted width, bed exposure, and streamflow) were estimated at each site (reach average for transects) using methods presented in Steuer and others (2009; table 2). Derivative hydraulic variables (stream power, shear stress, Froude and Reynolds numbers, and shear stress refuges) were calculated from the direct hydraulic estimates based on the formulae given in Statzner and others (1988). Transect refuge stress was calculated using transect-level estimates. A transect refuge metric was calculated by identifying the 2, 3, 4, 5, and 6 adjacent habitat transects with the lowest peak shear stress of the 11 transects at a site. This metric provided an approximation of a safe refuge from high flows. Model estimates for daily values of streamflow and direct and calculated derivative hydraulic variables were aggregated to monthly and annual time periods. Monthly and annual hydraulic variables were summarized as mean, maximum, and minimum values for each metric type. Monthly bed exposure was characterized by using only the mean value. Hydraulic metrics were divided into three groups based on the dominant way that the hydraulic metrics are perceived to affect benthic macroinvertebrates - bed disturbance, flow suitability, and habitat availability (table 2). Bed disturbance metrics included Froude number, Reynolds number, shear stress, transect shear stress refuge, and duration of shear stress greater than the threshold value expressed as the integration and duration of shear stress above threshold values of 1 , $2,5,25$, and 100 dynes/square centimeter $\left(\mathrm{cm}^{2}\right)$ across different numbers of adjacent transects. Flow suitability metrics included streamflow, channel velocity, power, and hydraulic depth. Habitat availability metrics included estimates of bed exposure percentage and wetted perimeter. Percentage of exposed streambed was calculated by subtracting wetted perimeter from estimated bed width and expressing this value as a percentage of bed width. Altogether, 303 hydraulic variables were available for analyses at each site in the MGB and RAL study areas. Steuer and others (2009; table 2) provide more information on the methods of calculations and hydraulic metric definitions. Relations of hydraulic and invertebrate metrics to urbanization were examined by using Spearman rank correlations. 
Table 2. Description of hydraulic metrics modeled from measurements of stream stage and channel geometry (adapted from Steuer and others, 2009).

$\left[\mathrm{cm}^{2}\right.$, square centimeters; d, days; $\mathrm{m}^{3}$, cubic meters; \%/d, percent per day; $\mathrm{m}$, meters; frac expos, fraction exposed; wet perim, wetted perimeter; $\mathrm{m} 3 / \mathrm{s}$, cubic meters per second; GT, greater than; GTd, days greater than; hyd depth, hydraulic depth; N/m/s, newtons per meter per second; m/s, meters per second]

\begin{tabular}{|c|c|c|}
\hline Hydraulic metric & Interval & Summarized as \\
\hline \multicolumn{3}{|l|}{ Bed disturbance } \\
\hline $\begin{array}{l}\text { Reynolds number (Reynolds): magnitude of turbulence in the flow as described } \\
\text { by the ratio of the inertial to viscous forces (unitless) }\end{array}$ & Monthly, annual & Mean, max, min \\
\hline Shear stress (Shear): measure of all forms of flow resistance $\left(\right.$ dynes $\left./ \mathrm{cm}^{2}\right)$ & Monthly, annual & Mean, max, min \\
\hline \multicolumn{3}{|l|}{ Shear stress greater than threshold value } \\
\hline $\begin{array}{l}\text { Integrated value (Shear GT): sum of shear stress }\left(\text { dynes } / \mathrm{cm}^{2}\right) \text { values greater than } \\
\text { thresholds of } 1,2,5,25,100 \text { dynes } / \mathrm{cm}^{2}\end{array}$ & Annual & Sum \\
\hline $\begin{array}{l}\text { Integrated days (Shear GTd): number of days (d) above thresholds of } 1,2,5,25 \text {, } \\
\text { and } 100 \text { dynes } / \mathrm{cm}^{2}\end{array}$ & Annual & Sum \\
\hline $\begin{array}{l}\text { Shear stress refuge (Refuge): mean shear stress in } 1 \text { to } 6 \text { adjacent transects with } \\
\text { lowest shear values under maximum shear stress conditions }\left(\text { dyne } / \mathrm{cm}^{2}\right)\end{array}$ & Annual & Mean \\
\hline Froude number (Froude): ratio of inertial to gravitational forces (unitless) & Monthly, annual & Mean, max, min \\
\hline \multicolumn{3}{|l|}{ Flow suitability } \\
\hline Channel velocity, $\mathrm{m} / \mathrm{s}$ & Monthly, annual & Mean, max, min \\
\hline Streamflow, $\mathrm{m}^{3} / \mathrm{s}$ & Monthly, annual & Mean, $\max , \min$ \\
\hline Hydraulic depth (Hyd depth): flow area/flow width (m) & Monthly, annual & Mean, $\max , \min$ \\
\hline Power: energy available to transport sediment $(\mathrm{N} / \mathrm{m} / \mathrm{s})$ & Monthly, annual & Mean, max, min \\
\hline \multicolumn{3}{|l|}{ Habitat availability } \\
\hline Fraction exposed (Frac expos): mean percentage of bed exposed $(\% / d)$ & Monthly, annual & Mean, $\max , \min$ \\
\hline Wetted perimeter (Wet perim): channel perimeter underwater $(\mathrm{m})$ & Monthly, annual & Mean, max, min \\
\hline
\end{tabular}

\section{Invertebrate Data and Metrics}

Two types of samples (Moulton and others, 2002) were used to provide a quantitative characterization of the riffle habitat (richest targeted habitat, RTH sample) and qualitative representation of the entire sampling reach (qualitative multihabitat, QMH sample). RTH samples were obtained by combining slack [500-micron $(\mu \mathrm{m})$ mesh] samples collected from five RTH locations [0.25 square meter $\left(\mathrm{m}^{2}\right)$ per sample] within the sampling reach $(300 \mathrm{~m})$. The RTH areas in MGB were runs, and riffles were the RTH in RAL. QMH samples were obtained by sampling all accessible habitats within the sampling reach in approximate proportion to their occurrence in the stream reach. QMH samples were collected using a D-frame kick $500-\mu \mathrm{m}$ net supplemented by substrate handpicking. Samples were processed in the field to remove debris, preserved in a 5-percent formalin solution, and shipped to the USGS National Water Quality Laboratory in Denver, Colorado, for identification and quantification (Moulton and others, 2000).
RTH samples were used to derive abundance and richness metrics describing riffle habitat assemblages (table 3). QMH and RTH samples were combined to produce a synthetic sample (QQ) from which richness metrics were derived to provide a qualitative (presence or absence) representation of assemblages within the entire sampling reach. The USGS Invertebrate Data Analysis System (IDAS; version 3.9.5, Cuffney, 2003) was used to derive the QQ sample, resolve taxonomic ambiguities (Cuffney and others, 2007), convert RTH abundances to densities (number per square meter), and calculate assemblage taxonomic, tolerance, diversity, and functional group metrics (Barbour and others, 1999). Metrics based on velocity preferences, body form, and voltinism were calculated from data compiled by Vieira and others (2006, table D-1). MGB and RAL tolerance metrics were calculated by using tolerance values for the Midwest and Southeast, respectively (Barbour and others, 1999). Southeast tolerance and functional group data were supplemented with data from the North Carolina Department of Environment and Natural Resources (North Carolina Department of Environment and Natural Resources, 2006). 
Table 3. Definitions and sources of information for the invertebrate richness and abundance metrics used in this study.

\begin{tabular}{|c|c|c|}
\hline Abbreviation & Definition & Source \\
\hline Total & Total number & Cuffney (2003) \\
\hline EPT & $\begin{array}{c}\text { Ephemeroptera }+ \\
\text { Plecoptera }+ \\
\text { Trichoptera }\end{array}$ & Cuffney (2003) \\
\hline EPEM & Ephemeroptera & Cuffney (2003) \\
\hline PLECO & Plecoptera & Cuffney (2003) \\
\hline $\mathrm{CH}$ & Chironomidae & Cuffney (2003) \\
\hline EPT_CH & $\begin{array}{l}\text { Ratio of EPT taxa to } \\
\text { chironomidae }\end{array}$ & Cuffney (2003) \\
\hline AVE_TOL & Mean tolerance & Cuffney (2003) \\
\hline INTOL & Intolerant taxa & Cuffney (2003) \\
\hline TOL & Tolerant taxa & Cuffney (2003) \\
\hline DVF & $\begin{array}{l}\text { Dorso-ventrally } \\
\text { flattened }\end{array}$ & Vieira and others (2006) \\
\hline StmFus & $\begin{array}{l}\text { Streamlined or } \\
\quad \text { fusiform }\end{array}$ & Vieira and others (2006) \\
\hline VoltGT1 & $\begin{array}{l}\text { Voltinism (more than } \\
1 \text { generation per } \\
\text { year) }\end{array}$ & Vieira and others (2006) \\
\hline Volt1 & $\begin{array}{l}\text { Voltinism ( } 1 \text { genera- } \\
\text { tion per year) }\end{array}$ & Vieira and others (2006) \\
\hline VoltLT1 & $\begin{array}{l}\text { Voltinism (less than } \\
1 \text { generation } \\
\text { per year) }\end{array}$ & Vieira and others (2006) \\
\hline Slow & Prefer slow water & Vieira and others (2006) \\
\hline Riffle & Prefer riffles & Vieira and others (2006) \\
\hline $\mathrm{CG}$ & Collector-gatherers & Cuffney (2003) \\
\hline $\mathrm{SC}$ & Scrapers & Cuffney (2003) \\
\hline $\mathrm{CN}$ & Clingers & Cuffney (2003) \\
\hline $\mathrm{FC}$ & Filtering-collectors & Cuffney (2003) \\
\hline MolCru & Mollusks / crustaceans & Cuffney (2003) \\
\hline Amphi & Amphipoda & Cuffney (2003) \\
\hline Shannon & Shannon diversity & Cuffney (2003) \\
\hline
\end{tabular}

\section{Invertebrate Responses to Urbanization and Hydraulics}

Relations of invertebrate and hydraulic metrics to urbanization were examined by using three lines of evidence: Spearman rank correlations (SPSS, 2007), recursive partitioning (rpart, Therneau and Atkinson, 2010), and BEST (BVSTEP, Clarke and Gorley, 2006) analyses. Correlation analysis was used to identify statistically significant $(p \leq 0.05)$ associations between pairs of variables. Recursive partitioning and BEST analyses were used to select predictor variables (individually and in combination) that were most closely associated with response variables. Recursive partitioning is a tree-based exploratory modeling method that identifies an important predictor variable and value at each successive split of the dataset by selecting the variable and value that maximizes the reduction in deviance for that split of the dataset. Minimum cross-validation error was used to prune the model and select a subset of predictor variables that described the response. BEST analyses compare the correlation (Spearman rank) between site-similarity matrices defined by the response variable (invertebrate metric or assemblage data) and combinations of the predictor variables (urban intensity and hydraulic metrics). Permutation tests determined the probability that the observed correlation occurred by chance. Predictor variables were standardized $($ mean $=0$, standard deviation $=1)$ prior to calculating similarities among sites based on Euclidean distance. Assemblage metrics and abundances were $\log (\mathrm{X}+1)$ transformed before similarities among sites were calculated (Euclidean distance for metrics, Jaccard similarity for qualitative assemblage data, and Bray-Curtis for the quantitative assemblage data).

\section{Hydraulic Metrics and Urban Intensity}

Urbanization was found to have an effect on hydraulic characteristics of streams in RAL and MGB. The time of year when urban effects on hydraulic metrics were most apparent differed in RAL and MGB, as evidenced by comparing mean values associated with low $(\mathrm{MA}-\mathrm{NUII} \leq 10)$ and high (MANUII $\geq 70$ ) urbanization. The RAL study area had large differences between sites with high and low urban intensities during the spring (March, April) for most of the bed disturbance (fig. 3) and flow suitability metrics (fig. 4), but not for habitat availability metrics (fig. 5). In contrast, the MGB study area had the largest differences during the summer months (July, August), though these differences were of a lesser magnitude than those observed in RAL. Habitat availability metrics (fig. 5) had different patterns with seasonal trends in the fraction of streambed exposed, but wetted perimeter remained fairly constant throughout the year. The fraction of streambed exposed was consistently larger at high urban-intensity sites in MGB, and the largest differences were associated with fall and winter (September through February). RAL had much smaller differences in bed exposure metrics between high and low urban-intensity sites with both showing a tendency for the fraction of exposed streambed to increase during the growing season (March through September). Low urban-intensity sites in RAL had consistently higher wetted perimeters than did high urban-intensity sites. The opposite trend was evident in MGB, though the differences in MGB are not statistically significant. The seasonal patterns of hydraulic metrics were evident regardless of the statistic (maximum, mean, or minimum) used to derive the monthly values from daily values. 
MGB
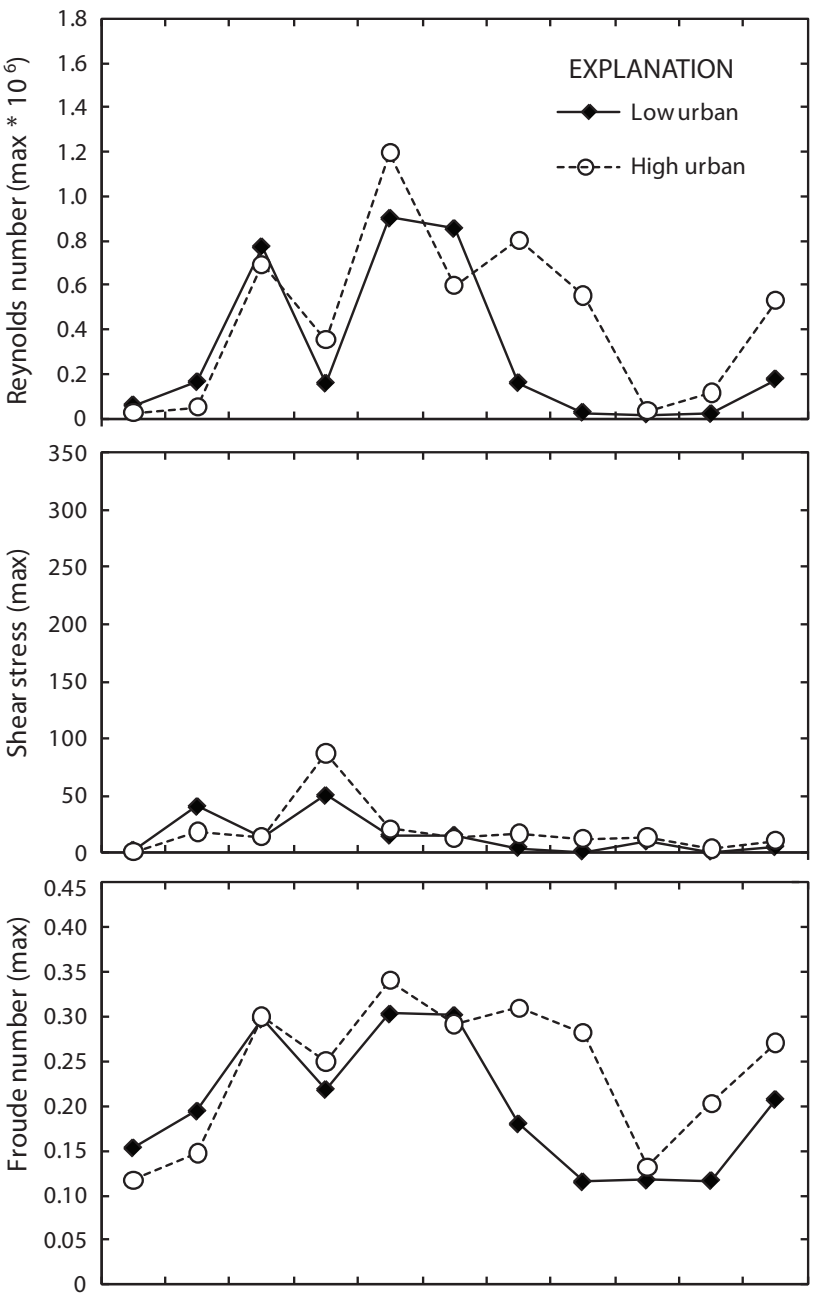

Jan. Feb. Mar. Apr. May June July Aug. Sept. Oct. Dec.
RAL
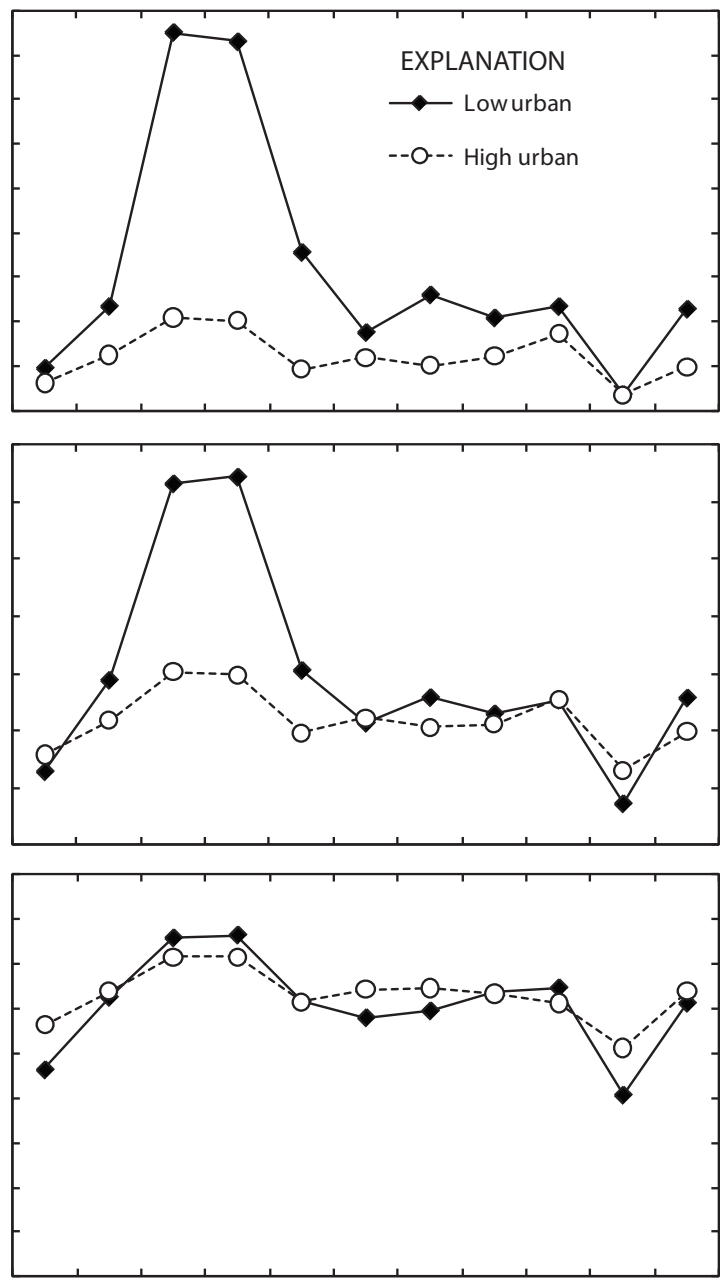

Jan. Feb. Mar. Apr. May June July Aug. Sept. Oct. Dec.

Figure 3. Annual patterns in hydraulic metrics representing bed disturbance for high (MA-NUII $\geq 70$ ) and low (MA-NUII $\leq 10)$ urban-intensity sites in the Milwaukee-Green Bay and Raleigh metropolitan areas.

Summaries of annual values of hydraulic metrics also showed differences between metropolitan areas and sites with high and low urban intensities (fig. 6). Reynolds number (maximum), shear stress (maximum, days $>5$ dynes, and three-transect refuge), and streamflow (maximum) were significantly higher in low urban-intensity sites in RAL than in low urban-intensity sites in MGB. In contrast, hydraulic metrics were similar at high urban-intensity sites in MGB and RAL with a significant difference in only maximum shear stress. Differences between sites with high and low urban intensities were greater in RAL where five metrics (maximum Reynolds number, three-transect refuge, maximum flow, maximum velocity, and maximum hydraulic depth) had significant differences compared to only one (fraction of bed exposure) in MGB. The fraction of streambed exposed was significantly different between high and low urban-intensity sites in MGB; high urban-intensity sites had much higher bed exposure than low urban-intensity sites. In contrast, the fraction of bed exposure in RAL did not differ between sites with high and low urban intensity, and the fraction was similar to sites with high urban intensity in MGB. As with the temporal monthly characterization of metrics, the statistic used to summarize the annual values (mean, maximum, and minimum) did not have a large effect on the comparisons.

Correlation, CART, and BEST analyses supplemented the graphical comparisons of the effects of urbanization on hydraulic metrics through examination of the correspondence with urban intensity across the entire urban gradient. Of the 303 hydraulic metrics, 53 were significantly correlated with urban intensity in MGB compared to 15 in RAL (63 hydraulic metrics total, table 4). Only five hydraulic metrics were significantly correlated in both MGB and RAL. They include Reynolds number, flow, hydraulic depth, velocity, and bed exposure. The correlations (positive / negative) for these five 

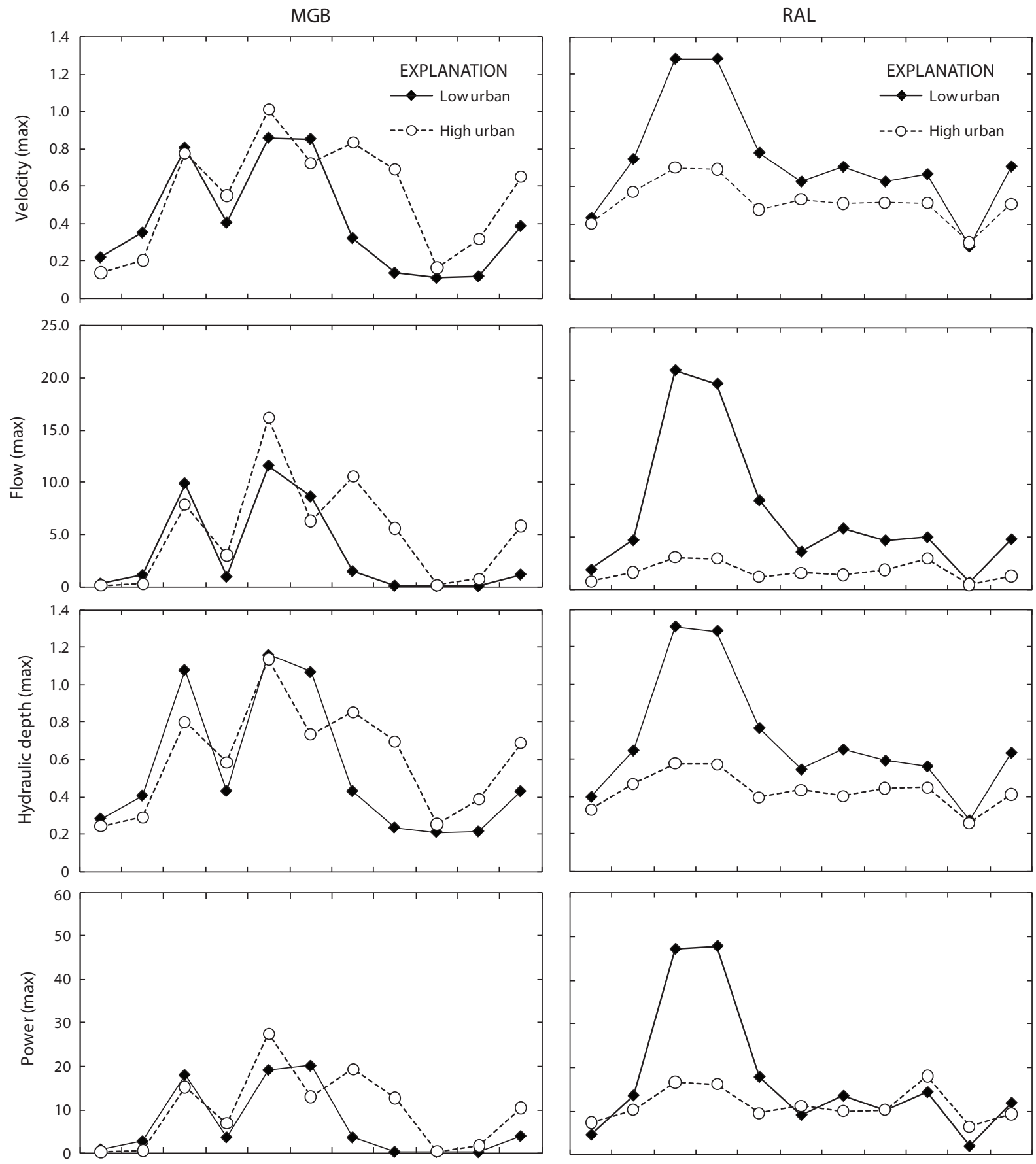

Jan. Feb. Mar. Apr. May June July Aug. Sept. Oct. Dec.

Jan. Feb. Mar. Apr. May June July Aug. Sept. Oct. Dec.

Figure 4. Annual patterns in hydraulic metrics representing flow suitability for high (MA-NUII $\geq 70$ ) and low (MA-NUII $\leq 10$ ) urban-intensity sites in the Milwaukee-Green Bay and Raleigh metropolitan areas. 
MGB
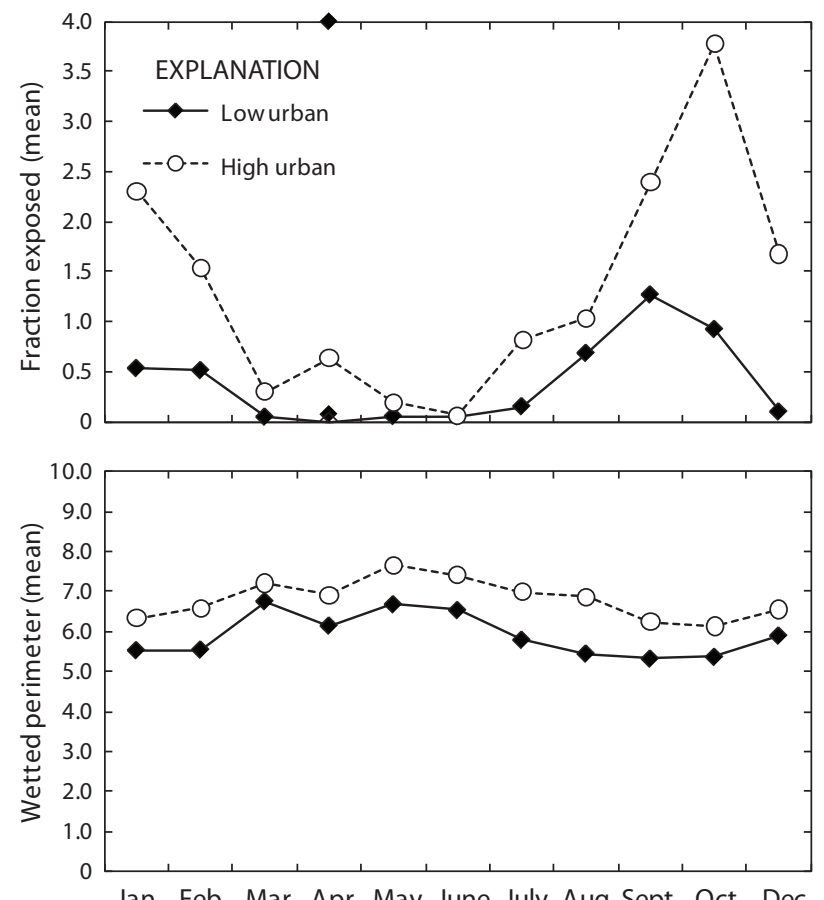

RAL
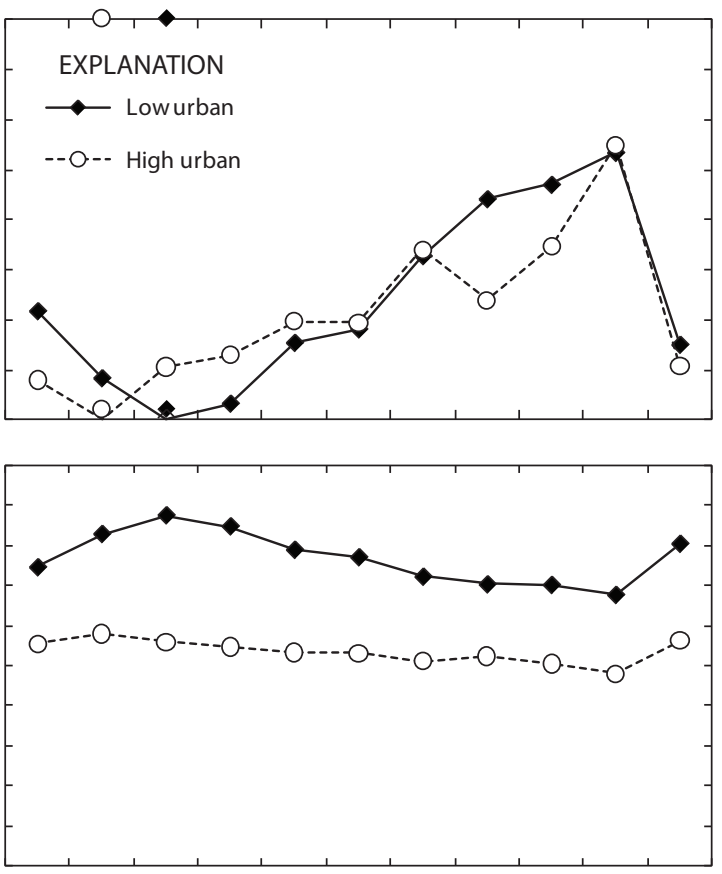

Jan. Feb. Mar. Apr. May June July Aug. Sept. Oct. Dec.

Figure 5. Annual patterns in hydraulic metrics representing bed exposure in high (MA-NUII $\geq 70$ ) and low (MA-NUII $\leq 10)$ urban-intensity sites in the Milwaukee-Green Bay and Raleigh metropolitan areas.

metrics were consistent between the two metropolitan areas. The strongest correlations in MGB were associated with summer (maximum values in August) for Reynolds number, shear stress, Froude number, velocity, streamflow, and hydraulic depth. In contrast, the strongest correlations in RAL were associated with spring (March or April) for Reynolds number, velocity, streamflow, bed exposure, and annual measures of hydraulic metrics (shear stress, streamflow). These time periods are consistent with the months that had the largest differences between sites with high and low urban-intensity (figs. 3-5).

Significant correlations in RAL were all of similar magnitude (values from 0.3 to 0.5 absolute), occurred in all hydraulic metric categories except Froude number, and were negative with the exception of bed exposure. Significant correlations in MGB occurred in all hydraulic metric categories except wetted perimeter, were positively correlated most frequently (45 of 53 metrics) with urban intensity, and generally were of larger magnitude (absolute correlation coefficient values from 0.4 to 0.7 absolute) than in RAL. The majority of the hydraulic metrics that were significantly correlated with urbanization in MGB or RAL were derived from monthly (58 of 63) rather than annual ( 5 of 63) metrics. Maximum values were correlated most often with urbanization (39), followed by mean (20) and minimum daily values (4). This is consistent with the previous observation that the temporal patterns of hydraulic metrics at sites with high and low urban intensities were largely independent of the summary statistic (mean, maximum, minimum).

Differences in the number and types of hydraulic metrics that were significantly correlated with urbanization in RAL and MGB indicate that the effects of urbanization on hydraulic characteristics differ substantially between these two metropolitan areas. The larger number of significantly correlated hydraulic metrics in MGB indicates that urbanization has a greater effect on hydraulic characteristics in MGB than in RAL. These differences most likely arise from regional differences in natural factors (for example, temperature, precipitation, topography, soils, and geomorphology) and anthropogenic factors (for example, agriculture and urbanization; table 1) that create and alter the natural pattern of streamflow.

The CART and BEST analyses provided a sharp contrast to the correlation analyses. Only one hydraulic metric (Hyd depth, August maximum) was associated with urban intensity in the MGB CART analysis and none in RAL despite using a tree-pruning method that tends to overfit the model. BEST analysis also did not reveal a single (or combination) hydraulic metric that was more strongly correlated with the site similarity matrix defined by urban intensity than a random permutation of the data. The apparent discrepancy between the correlation analyses and the CART and BEST analyses can be accounted for by correcting the a-level in the correlation analyses to reflect the number of comparisons (303). For equitable comparison, results from the correlation analysis were adjusted for multiple comparisons using Sidak's 


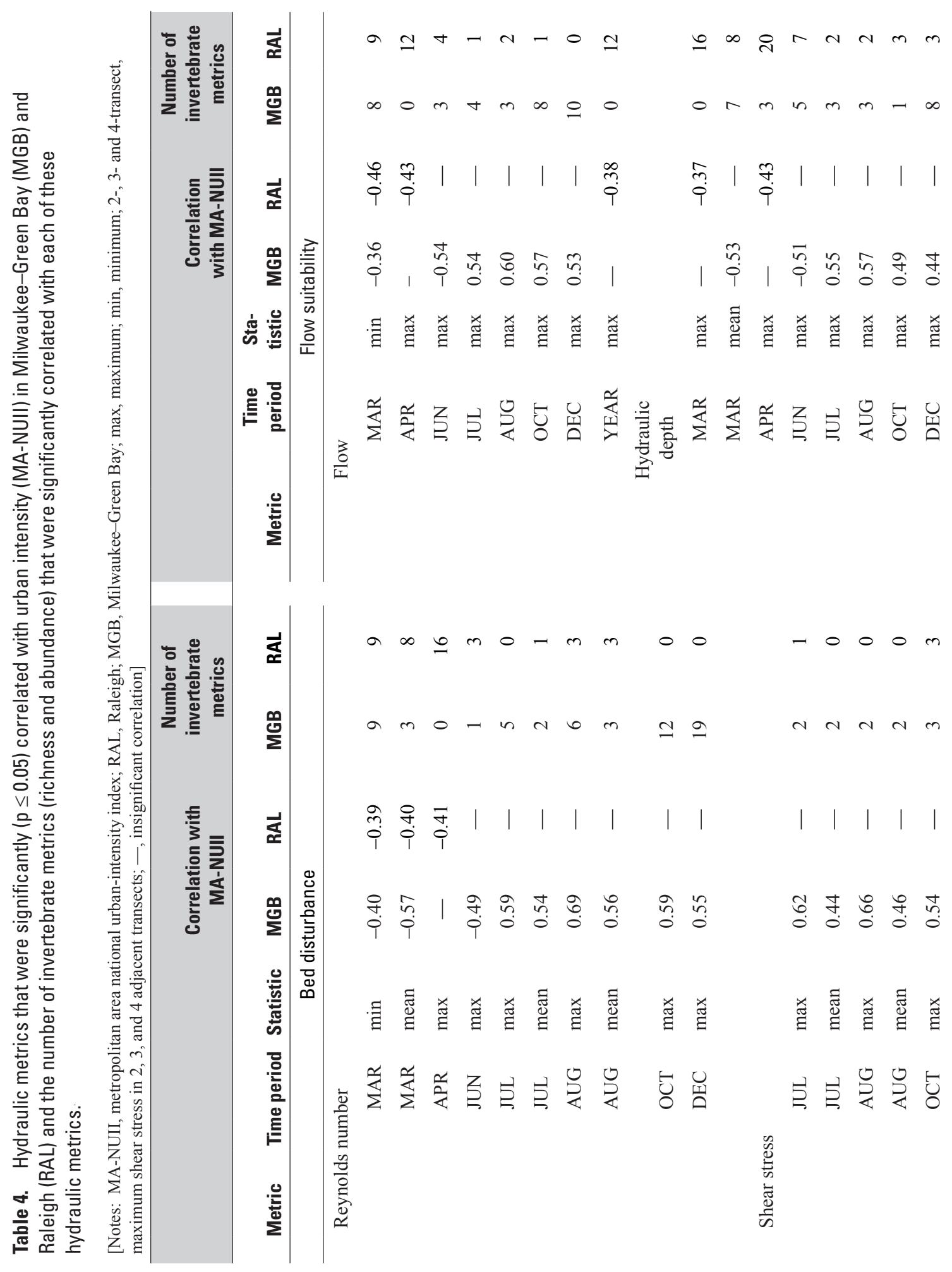




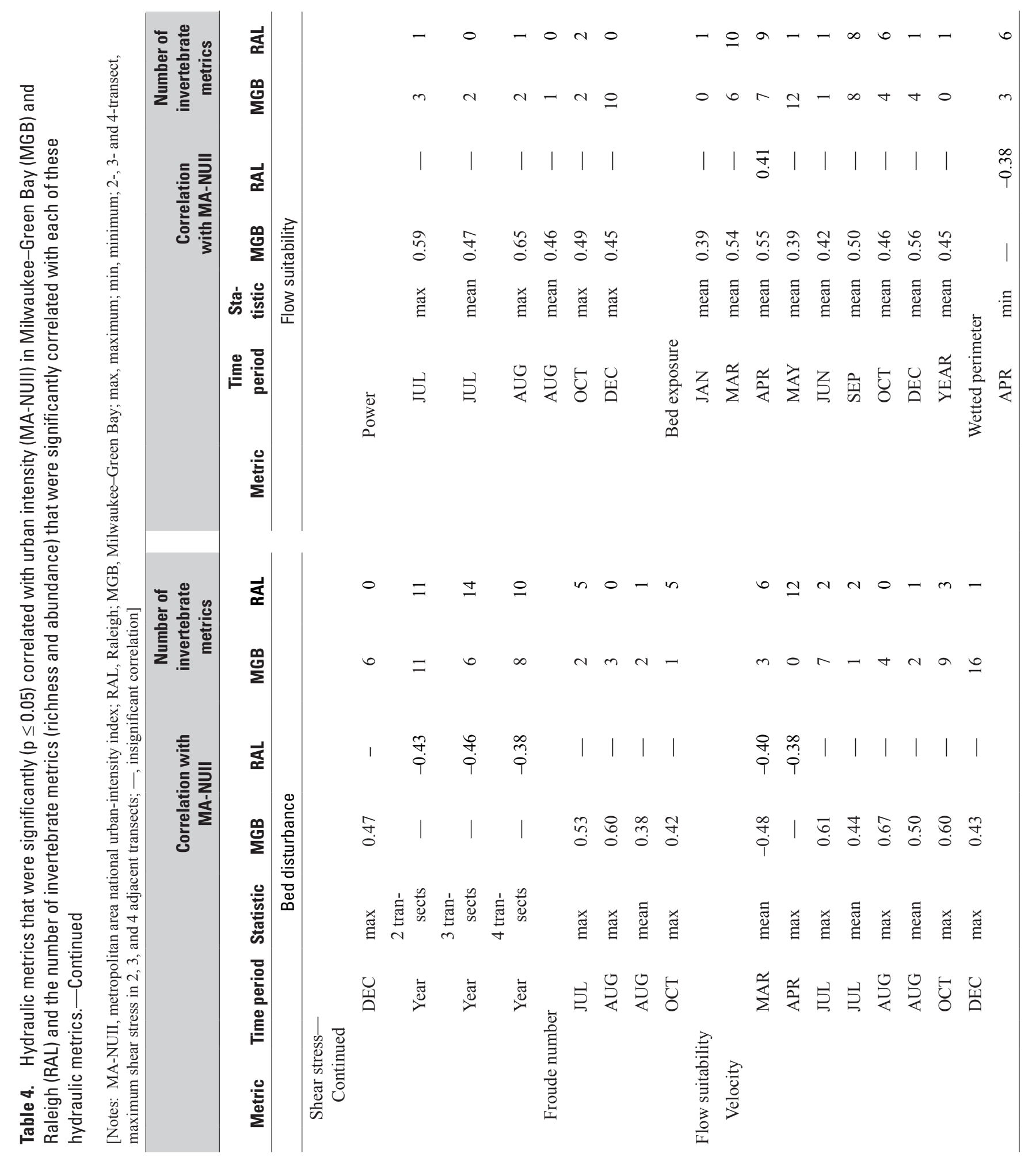



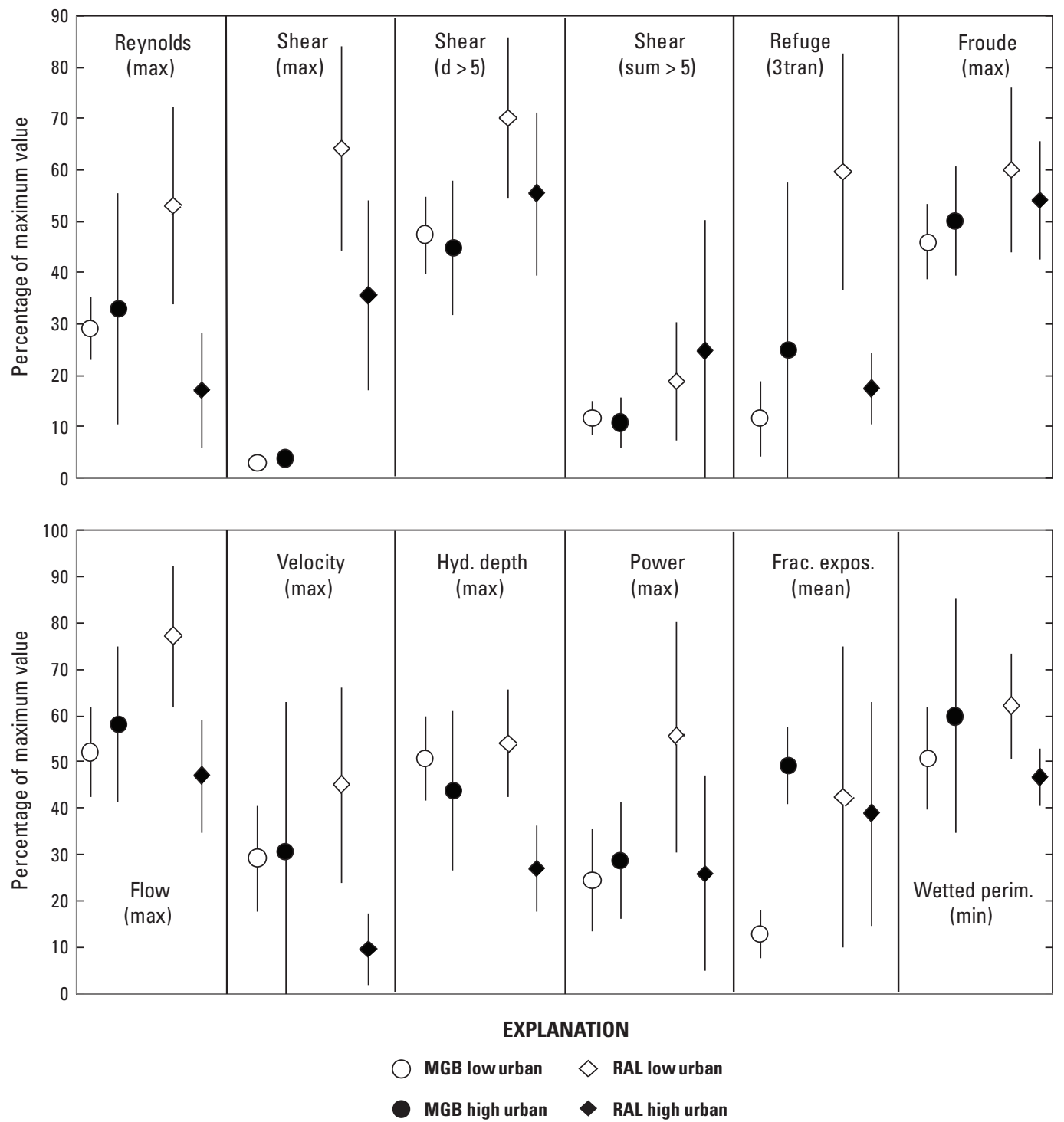

Figure 6. Hydraulic metrics for low (MA-NUII $\leq 10$ ) and high (MA-NUII $\geq 70$ ) urban-intensity sites in Milwaukee-Green Bay (MGB) and Raleigh (RAL) based on annual statistics.

and Bonferroni's corrections. This resulted in an a-level of $<0.0002$. With this adjustment, all analyses (correlation, CART, and BEST) agree that the correlations between MANUII and hydraulic metrics listed in table 4 are statistically insignificant. Because correlation is one of the analysis methods, it should not be used to describe the commonality.

Special attention was given to variability in the flashiness of streamflow. Increases in flashiness, defined as increased frequency of short duration high flows coupled with longer duration low flows, commonly are described as an effect of urbanization. On this basis, sites with high urbanization (MA-NUII $\geq 70$ ) would be expected to have higher maximum streamflows, higher maximum velocities, and lower minimum wetted perimeters than sites with low $(\mathrm{MA}-\mathrm{NUII} \leq 10)$ urbanization. Neither RAL nor MGB fit this expected result. RAL had higher values for maximum streamflow and velocity at sites with low urbanization than at sites with high urbanization (fig. 6). RAL also had a marked increase in maximum streamflow and velocity at low urban-intensity sites during spring months (March and April) while sites with high urbanization had relatively little change throughout the year. In contrast, MGB had a different response pattern with more variability in maximum streamflow and velocity during the year, less of a difference between sites with high and low urbanization as compared to RAL, and maximum differences during summer (July and August).

Minimum wetted perimeter was consistently greater at low urban-intensity sites in RAL, which typically are forested, than at high urban-intensity sites; however, the pattern in MGB was exactly the opposite (fig. 6). Differences in minimum wetted perimeter between sites with high and low urbanintensity were relatively constant in both RAL and MGB; however, RAL had a larger difference than MGB and a slight increase during the spring months (March and April) (fig. 5). 
Bed exposure (percentage) in RAL was higher at sites with high urban-intensity than at sites with low urban intensity in the spring and early summer (March through May) and lower at sites with high urban intensity than at sites with low urban intensity in late summer (August through September). Overall, bed exposure tended to increase from late winter to early fall regardless of the degree of urbanization. Sites with high urban intensity in MGB had consistently higher bed exposure than did sites with low urban intensity. As in RAL, bed exposure in MGB tended to increase during the year, though the increase in MGB started later in the year (June) than in RAL (March).

The apparent contradiction between the expected and observed responses for indicators of flashiness appears to be a consequence of summarizing hydraulic characteristics monthly or annually on the basis of daily values. This method of summarization reduces the influence of short-duration high flows and emphasizes longer-duration low flows. Analysis of the frequency and duration of flows based on hourly stage data (fig. 7) resulted in expected increases in flashiness with increases in urbanization. Stage rises were more frequent and for shorter durations at sites with high urban intensity than at sites with low urban intensity in MGB and RAL. Durations of low flows also were higher at sites with low urban intensity than at sites with high urban intensity in MGB and RAL, though the difference was not statistically significant ( $p>0.05$, non-significance based on overlap of 95-percent confidence bands in fig. 7) in RAL. These results support the need for more temporally intensive measurements of flow characteristics; however, missing values (hourly) of stage did not allow flow characterization at a finer temporal resolution.

Hydraulic responses to urbanization in RAL and MGB were markedly different, both in terms of the number of hydraulic metrics that were associated with urbanization and the seasonality of the strongest correlations (primarily summer in MGB and spring in RAL). Comparison of RAL and MGB sites with low ( $\leq 10$ percent) and high ( $>70$ percent) urbanintensity values illuminate the climatic influence, particularly for hydraulic metrics in the flow suitability and habitat availability classes - maximum streamflow, maximum velocity, minimum wetted perimeter, and mean bed exposure. Peak rainfall in MGB coincides with peak summer temperatures, thus providing a mechanism for sustaining streamflow when evapotranspiration demands are high. In contrast, precipitation in RAL is relatively constant throughout the year, so high summer evapotranspiration is reflected in reduced streamflows. Evapotranspiraton in RAL would be expected to be highest in heavily forested areas in contrast to urban areas that have reduced vegetation (considering evaporation), which explains the larger reductions observed in flow and velocity during the summer in RAL between high and low urban-intensity sites (fig. 4) and the differences in bed exposure and wetted perimeter between RAL and MGB (fig. 5). Consequently, while urbanization affects streamflow in RAL and MGB, regional differences in land cover (forest in RAL, agriculture in MGB) and precipitation affect how the influences of urbanization on stream hydrology are expressed.

\section{Hydraulic Metrics and Invertebrate Responses}

Only a small percentage (6.4-6.8) of the correlations between invertebrate and hydraulic metrics were statistically significant $(\mathrm{p} \leq 0.05)$ in either MGB or RAL (table 5). The majority of these correlations (about 94 percent) were significant in only one metropolitan area though the percentages of

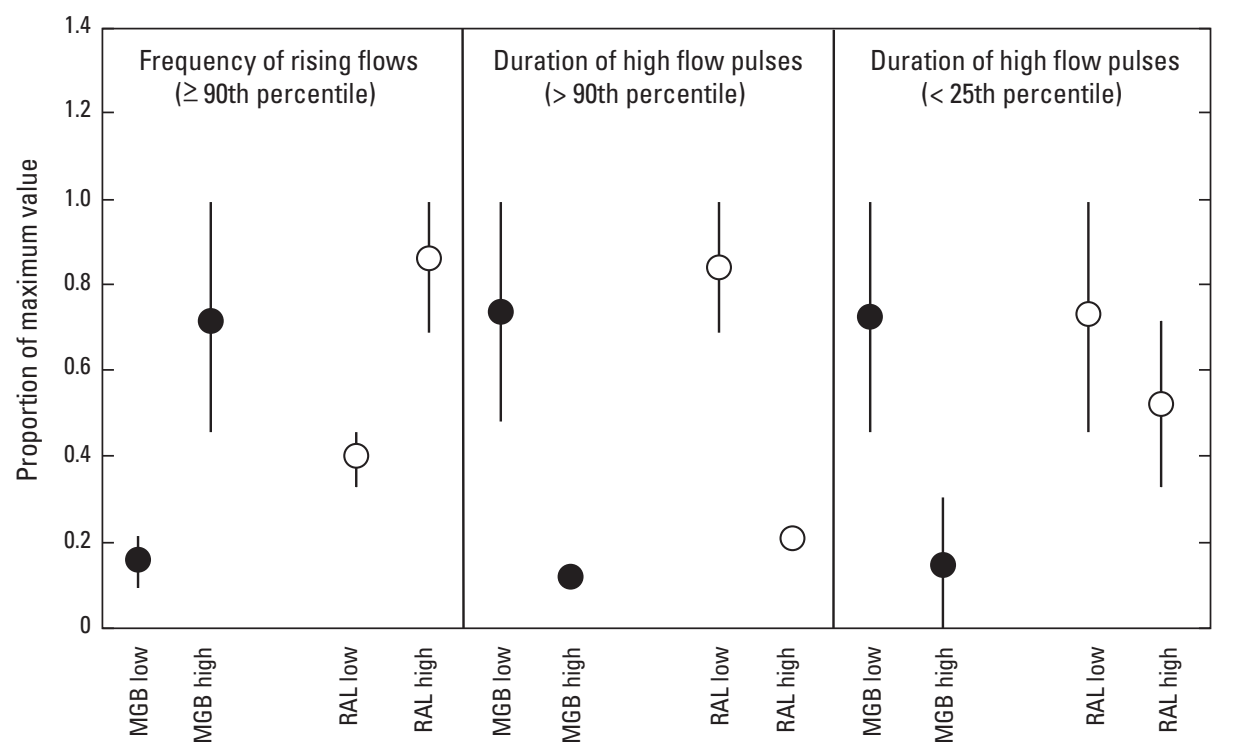

Figure 7. Frequency and duration of streamflow based on hourly stage data in Milwaukee-Green Bay (MGB) and Raleigh (RAL) based on annual statistics. 
correlations that were significant in both metropolitan areas were fairly similar. The highest percentages of significant correlations were associated with Reynolds number, refuge, flow, velocity, and hydraulic depth in MGB and RAL. Only a small percentage of the hydraulic metrics that were significantly correlated with invertebrate metrics in MGB (18) and RAL (5) also were significantly correlated with urbanization (table 4). The number of invertebrate metrics that were significantly correlated with the urban hydraulic metrics listed in table 4 were nearly three times higher in RAL $(20 \pm 2.0$ standard error) than in MGB ( $7 \pm 0.7$ standard error) despite MGB having more hydraulic metrics that were significantly correlated with urbanization than RAL.

Table 5. Number (No.) and percentage (percent) of statistically significant correlations between hydraulic and invertebrate metrics in Milwaukee-Green Bay (MGB), Raleigh (RAL), and both RAL and MGB (Common).

\begin{tabular}{lrrrrrr}
\hline & \multicolumn{2}{c}{ MGB } & \multicolumn{2}{c}{ RAL } & Common \\
\hline $\begin{array}{l}\text { Hydraulic } \\
\text { metric } \\
\text { (see table 2) }\end{array}$ & No. & $\%$ & No. & $\%$ & No. & $\%$ \\
\hline Reynolds & 192 & 11.9 & 125 & 7.7 & 12 & 0.7 \\
Shear & 78 & 4.8 & 49 & 3.0 & 3 & 0.2 \\
Shear_GT & 4 & 1.8 & 0 & 0 & 0 & 0 \\
Shear_GTd & 15 & 6.7 & 0 & 0 & 0 & 0 \\
Refuge & 33 & 14.7 & 51 & 22.7 & 0 & 0 \\
Froude & 86 & 5.3 & 67 & 4.1 & 2 & 0.1 \\
Velocity & 154 & 9.5 & 106 & 6.5 & 13 & 0.8 \\
Flow & 112 & 10.4 & 76 & 7.0 & 3 & 0.3 \\
Hyd. depth & 134 & 8.3 & 151 & 9.3 & 16 & 1.0 \\
Power & 65 & 4.0 & 52 & 3.2 & 3 & 0.2 \\
Fraction & & & & & & \\
$\quad$ exposed & 42 & 7.8 & 47 & 8.7 & 0 & 0 \\
Wetted & & & & & & \\
$\quad$ perimimeter & 14 & 0.9 & 146 & 9.0 & 2 & 0.1 \\
\hline Total & $\mathbf{9 2 9}$ & $\mathbf{6 . 8}$ & $\mathbf{8 7 0}$ & $\mathbf{6 . 4}$ & $\mathbf{5 4}$ & $\mathbf{0 . 4}$ \\
\hline
\end{tabular}

Correlation analysis revealed significant correlations between hydraulic and invertebrate metrics for all richness (table 6) and abundance metrics (table 7) in MGB and RAL. Little correspondence was noted between the two metropolitan areas, however, with only three richness $(\mathrm{CH}, \mathrm{TOL}$, and $\mathrm{SC})$ and five abundance (EPEM, INTOL, TOL, VOLTLT1, and CG) metrics being correlated with the same hydraulic metric in both metropolitan areas (see table 3 for definitions of abbreviations). Richness metrics were correlated most frequently with Reynolds number and velocity in MGB and with hydraulic depth in RAL. Abundance metrics in MGB were correlated most often with Reynolds number, Froude number, and refuge in MGB and with bed exposure and hydraulic depth in RAL.
Correlations between richness metrics and urbanization were higher $(|\rho|)$ for 19 of the 22 metrics in RAL compared with 3 of 22 metrics in MGB. In contrast, correlations between abundance metrics and urbanization were lower for 18 of 23 metrics in RAL than for those in MGB and for 21 of 23 metrics in MGB than for those in RAL.

CART and BEST analyses revealed far less correspondence between hydraulic and invertebrate metrics than did correlation analyses. Hydraulic metrics were identified as important explanatory variables for only two richness metrics $(\mathrm{CH}$ and EPT_CH) in MGB using CART analysis and none using BEST analysis (table 6). In contrast, hydraulic metrics were identified as important explanatory variables in RAL for three richness metrics (AMPHI, SLOW, and FC) using CART analysis and two (TOL and $\mathrm{CN}$ ) using BEST analysis. While these analyses ascribe some importance to hydraulic metrics, their importance was not comparable to urban intensity (MA-NUII), as was determined by comparing CART and BEST analyses with and without urban intensity as part of the explanatory variables. Incorporating urban intensity did not affect the results of the MGB CART and BEST analyses. However, it did have a strong effect on the RAL analyses, which identified urban intensity as an important predictor for 16 metrics using CART analysis and 13 metrics using BEST analysis. Urban intensity was identified as an important predictor variable in RAL in all cases where hydraulic metrics were identified as important predictors. Comparison of the strengths of the correlations of invertebrate metrics with urban intensity and hydraulic metrics showed that the correlation with urban intensity was stronger $(|\rho|)$ for 19 metrics in RAL and only 1 in MGB (see correlations noted with asterisks in table 6).

Invertebrate abundance metrics were correlated most often with Reynolds number, Froude number, and refuge in MGB and with fraction of streambed exposed and hydraulic depth in RAL, though CART and BEST analyses did not identify any of these hydraulic metrics as important predictors of abundance metrics in MGB and identified only three in RAL (table 7). Incorporating urban intensity into the analyses did not result in large increases in the number of associations with abundance metrics as was observed for richness metrics. Correlations with urban intensity were stronger than correlations with hydraulic metrics for three abundance metrics (VOLT1, RIFFLE, and FC) in MGB and four metrics (AVE_TOL, INTOL, SH_DVF, and CN) in RAL. Results of CART analyses were not affected by incorporating urban intensity in either MGB or RAL. BEST analyses identified urban intensity as a significant predictor for only two abundance metrics (PLECO and INTOL) in RAL and none in MGB.

The correlation, CART, and BEST analyses all confirmed that there is little comparability in the hydraulic metrics associated with invertebrate metrics in RAL and MGB and that urbanization influences invertebrate responses in RAL but not MGB. Collectively, these results indicate that the relations among invertebrate responses, urban intensity, and hydraulic conditions are fundamentally different in RAL and MGB. This 
Table 6. Explanatory variables (hydraulic metrics and urban intensity) associated with invertebrate richness metrics based on Spearman rank correlation and CART and BEST analyses for Milwaukee-Green Bay (MGB) and Raleigh (RAL).

[An asterisk indicates that the correlation with the urban-intensity index (MA-NUII) was greater than the correlation with the hydraulic metric. Footnotes identify instances where multiple variables were associated with responses in the CART and BEST analyses. ns, no variables remained in the CART analysis after pruning, or the correlation in the BEST analysis was not statistically significant; na, the invertebrate metric was not applicable for this analysis method; Ann, annual; Hyd, hydraulic; trans, transect; expos, exposure; perim, perimeter]

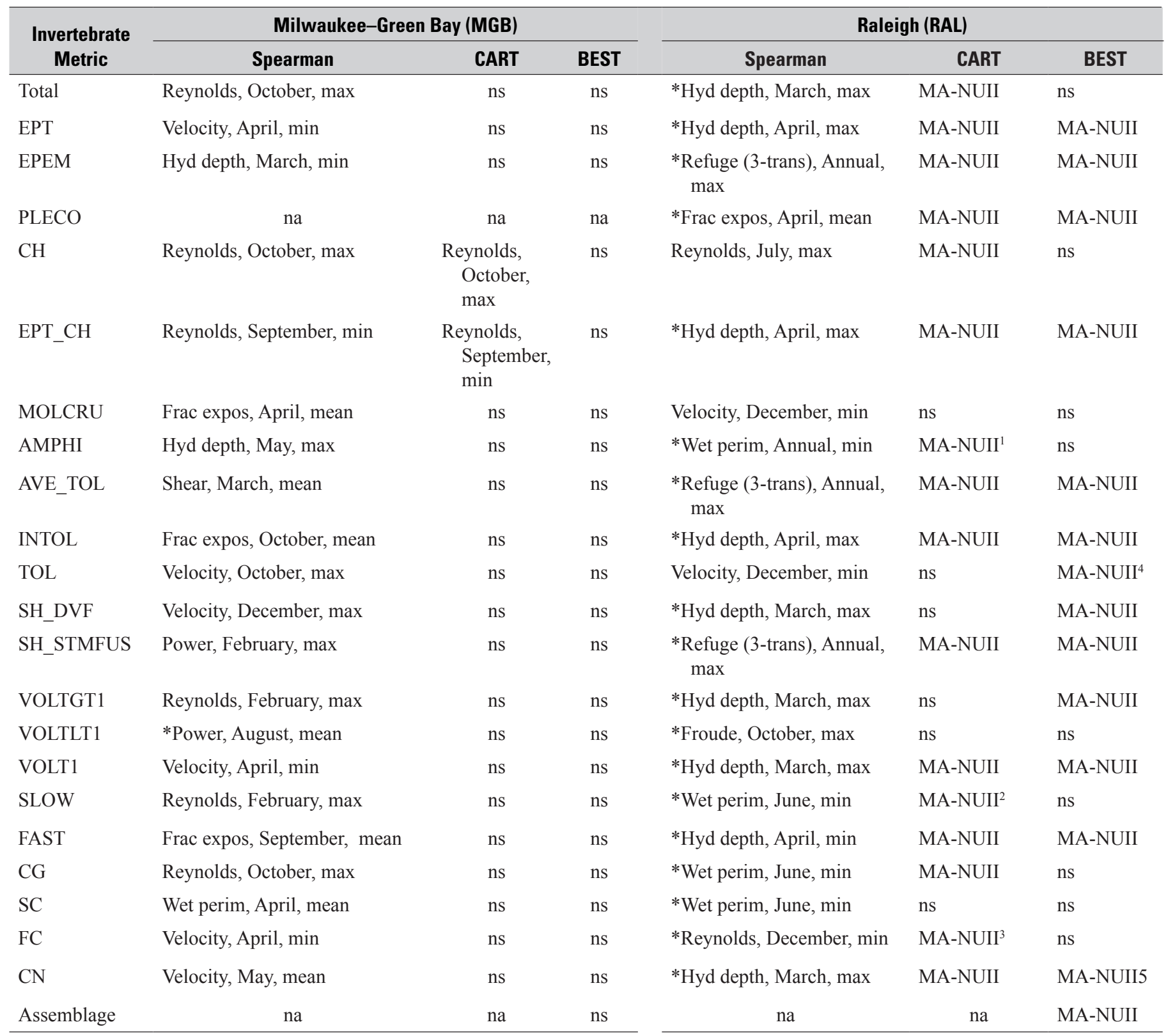

${ }^{1}$ MA-NUII; Reynolds, February, min; Froude, Annual, max

${ }^{2}$ MA-NUII; Froude, February, min; Froude, Annual max; Froude, January, min

${ }^{3}$ MA-NUII; Hyd depth, July, mean

${ }^{4}$ MA-NUII; Froude, December, min; Reynolds, October, max; Reynolds, October, mean; Reynolds, December, mean; Shear, April, min; Shear, May, min; Hyd depth, February, max; Hyd depth, March, mean

${ }^{5}$ MA-NUII; Reynolds, January, min; Power, June, max 
Table 7. Explanatory variables (hydraulic metrics and urban intensity) associated with invertebrate abundance metrics based on Spearman rank correlation and CART and BEST analyses in Milwaukee-Green Bay (MGB) and Raleigh (RAL).

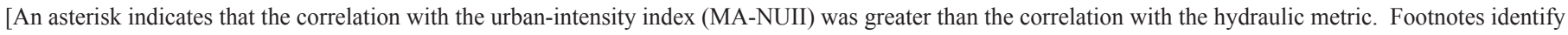

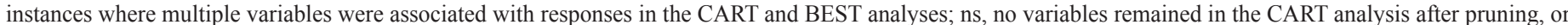

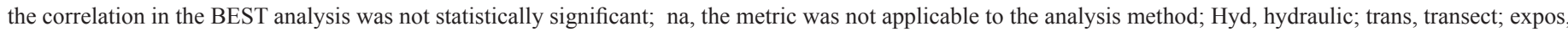
exposure; perim, perimeter]

\begin{tabular}{|c|c|c|c|c|c|c|}
\hline \multirow{2}{*}{$\begin{array}{l}\text { Invertebrate } \\
\text { Metric }\end{array}$} & \multicolumn{3}{|c|}{ Milwaukee-Green Bay (MGB) } & \multicolumn{3}{|c|}{ Raleigh (RAL) } \\
\hline & Spearman & CART & BEST & Spearman & CART & BEST \\
\hline Total & *Reynolds, May, max & ns & ns & $\begin{array}{l}\text { Hyd depth, September, } \\
\text { mean }\end{array}$ & ns & ns \\
\hline EPT & Flow, Oct, min & ns & ns & $\begin{array}{l}\text { Hyd depth, September, } \\
\max \end{array}$ & ns & ns \\
\hline EPEM & Hyd depth, June, min & ns & ns & $\begin{array}{l}\text { Hyd depth, January, } \\
\text { mean }\end{array}$ & ns & ns \\
\hline PLECO & na & na & na & Wet perim, May, min & ns & MA-NUII \\
\hline $\mathrm{CH}$ & Froude, June, max & ns & ns & $\begin{array}{l}\text { Wet perim, Annual, } \\
\max \end{array}$ & ns & ns \\
\hline EPT_CH & Reynolds, June, min & ns & ns & Flow, March, max & ns & ns \\
\hline MOLCRU & Refuge (2 trans), Annual, max & ns & ns & Reynolds, June, min & ns & $\begin{array}{l}\text { Froude, February, } \\
\max ^{1}\end{array}$ \\
\hline AMPHI & Reynolds, May, max & ns & ns & Froude, June, $\max$ & ns & ns \\
\hline AVE_TOL & Velocity, April, min & ns & ns & $\begin{array}{l}\text { *Refuge (3 trans), An- } \\
\text { nual, max }\end{array}$ & ns & ns \\
\hline INTOL & Frac expos, September, mean & ns & ns & $\begin{array}{l}\text { *Frac expos, April, } \\
\quad \text { mean }\end{array}$ & ns & MA-NUII \\
\hline TOL & Refuge (2 trans), Annual, max & ns & ns & $\begin{array}{l}\text { Refuge (3 trans), An- } \\
\text { nual, } \max \end{array}$ & ns & ns \\
\hline SHANNON & Froude, April, min & ns & ns & Frac expos, April, mean & ns & ns \\
\hline SH_DVF & Flow, December, max & ns & ns & $\begin{array}{l}\text { *Bed expos, Septem- } \\
\text { ber, mean }\end{array}$ & Velocity, June, $\max$ & ns \\
\hline $\begin{array}{l}\text { SH_STM- } \\
\text { FUS }\end{array}$ & Hyd depth, April, min & ns & ns & Flow, March, min & ns & ns \\
\hline VOLTGT1 & Froude, Annual, max & ns & ns & $\begin{array}{l}\text { Frac expos, March, } \\
\text { mean }\end{array}$ & ns & ns \\
\hline VOLTLT1 & Velocity, March, min & ns & ns & Velocity, March, min & ns & ns \\
\hline VOLT1 & *Reynolds, October, min & ns & ns & $\begin{array}{l}\text { Hyd depth, September, } \\
\text { mean }\end{array}$ & $\begin{array}{l}\text { Hyd depth, September, } \\
\text { mean }\end{array}$ & ns \\
\hline SLOW & Refuge (2 trans), Annual, max & ns & ns & Velocity, March, min & $\begin{array}{l}\text { Hyd depth, September, } \\
\text { mean }\end{array}$ & ns \\
\hline RIFFLE & *Froude, Annual, max & ns & ns & $\begin{array}{l}\text { Frac expos, March, } \\
\text { mean }\end{array}$ & ns & ns \\
\hline $\mathrm{CG}$ & Refuge (2 trans), Annual, max & ns & ns & $\begin{array}{l}\text { Refuge (3 trans), An- } \\
\text { nual, max }\end{array}$ & ns & ns \\
\hline $\mathrm{SC}$ & Reynolds, July, mean & ns & ns & $\begin{array}{l}\text { Wet perim, October, } \\
\text { min }\end{array}$ & ns & ns \\
\hline $\mathrm{FC}$ & *Flow, October, min & ns & ns & $\begin{array}{l}\text { Hyd depth, September, } \\
\text { mean }\end{array}$ & ns & ns \\
\hline $\mathrm{CN}$ & Froude, Annual, max & ns & ns & *Velocity, October, max & ns & ns \\
\hline Assemblage & na & na & na & na & na & MA-NUII \\
\hline
\end{tabular}

${ }^{1}$ Froude, February, max; Froude, July, max; Reynolds, April, max; Reynolds, October, mean; Reynolds, May, min; Hyd depth, April, max;

Hyd depth, September, max 
supports the contention that the effects of urbanization need to be examined and interpreted as a series of local or regional phenomena rather than as a single national phenomenon (Grimm and others, 2008). Variations in the climate (temperature, rainfall, and evapotranspiration) and background land cover (RAL forest, MGB agriculture) most likely account for these differences. The high levels of agriculture identified at background sites (MA-NUII $\leq 10)$ in MGB (76.1 \pm 2.4 standard error) compared to RAL (21.5 \pm 3.5 standard error) indicate that assemblages at these sites already have experienced considerable disturbance prior to urban development (Cuffney and others, 2010), which accounts for the poor associations between urban intensity and invertebrate metrics. Differences in the climate, topography, and geomorphology between MGB and RAL ensure that the timing and amount of runoff result in dissimilar hydrologic conditions, yielding different invertebrate responses across the urban gradient.

\section{Summary and Conclusions}

Correspondence among urbanization, hydraulics, and invertebrate communities were investigated by the U.S. Geological Survey National Water-Quality Assessment Program by using measures of stream hydraulics in two areas of the United States. Specifically, the hypothesis that the effects of urbanization on streamflow and aquatic biota are transferable across geographic regions was tested. Data from sites in Raleigh, North Carolina, and Milwaukee-Green Bay, Wisconsin, were evaluated to any correlation between increasing urbanization, hydraulic characteristics (Reynolds number, shear stress, and stream power for example), and invertebrate richness and abundance and the extent to which correlations were similar between urban areas.

Patterns in responses of invertebrates to hydraulics were not evident when invertebrate and hydraulic metrics were expressed at fine scales, that is, incorporating differences in time (month and year) and measurement (statistics). However, patterns in the correlations were discernable when comparisons were made on the basis of the class of hydraulic metric (for example Reynolds number or hydraulic depth) that was correlated most frequently or most strongly with invertebrate metrics. Spring months (March and April) were observed to be the most important period for hydraulic control of invertebrate assemblages in Milwaukee-Green Bay (MGB), Wisconsin, and Raleigh (RAL), North Carolina. This finding was evident when the statistic (maximum, minimum, mean) used to measure the hydraulic metric was ignored and the invertebrate metrics were combined to characterize the frequency of significant correlations with invertebrate metrics.

A higher degree of correspondence was observed in RAL than in MGB between the invertebrate metrics that were correlated most strongly with the dominant hydraulic metric (Reynolds number in MGB; hydraulic depth in RAL) and with urban intensity. This was expected given the deleterious effects of agriculture on invertebrate assemblages in MGB prior to urbanization. Consequently, analyses of the correlations based on the class of hydraulic metric (for example, not separating time or statistics) provided evidence supporting the control of hydraulic metrics by urbanization that subsequently affects the invertebrate assemblages. While suggestive of relations in the data, this evidence is far from conclusive, particularly given the lack of correspondence observed when time and statistics are considered. Similar analyses in other metropolitan areas are needed to determine if these relations occur in other regions.

The same general patterns of correlations among urbanization, hydraulic metrics, and invertebrate responses that were reported in an earlier study were observed in MGB. For example, significant correlations were observed between urban intensity and all classes of hydraulic metrics, except wetted perimeter, and the strongest correlations were in August and October. However, the strengths of the correlations between hydraulic and invertebrate metrics were less (maximum 0.67) than those reported in an earlier study (maximum 0.83) because the monthly and annual statistics for this study were derived from daily values as opposed to hourly values, as used in an earlier study. Daily values were used in this study because of the need to estimate missing data, which could be reliably estimated. Daily values also are the most commonly available hydrologic data. However, the better correspondence between invertebrate and hydraulic metrics reported in a previous study indicates that data at an hourly scale would be better for determining relations in the data.

The patterns derived from correlation analysis are tempered by results from the CART and BEST analyses that showed little evidence for hydraulic influences of invertebrate responses. These analyses also revealed that urbanization (MA-NUII) was the predominant factor controlling invertebrate responses in RAL but not in MGB. Invertebrate responses to urbanization were not observed in MGB because agricultural degradation prior to urbanization masks the hydraulic effects caused by urbanization. The differences between the results obtained by using correlation analysis and the results obtained by using CART and BEST analyses are a result of analyzing the significance of the correlations without adjusting for the number of comparisons. If the number of comparisons is taken into account, none of the correlations between invertebrate and hydraulic metrics were significant. Given the problems associated with using correlation as a method for identifying important associations, the results of the CART and BEST analyses represent the most reliable assessment of the importance of hydraulic metrics in predicting invertebrate responses.

Collectively, these results do not provide strong evidence that the effect of urbanization on hydraulic conditions in streams is the primary factor driving the changes observed in invertebrate assemblages along the urban gradient in either RAL or MGB. The differences observed between RAL and MGB support the idea that the effects of urbanization need to be examined and interpreted as a series of local or regional phenomena rather than as a single national phenomenon. 


\section{References}

Barbour, M.T., Gerritsen, J., Snyder, B.D., and Stribling, J.B., 1999, Rapid bioassessment protocols for use in streams and wadeable rivers-Periphyton, benthic macroinvertebrates, and fish ( $2 \mathrm{~d}$ ed.): Washington, D.C., U.S. Environmental Protection Agency, Office of Water, accessed March 16, 2011, at http://www.epa.gov/owow/monitoring/rbp/.

Booth, D.B., and Jackson, C.J., 1997, Urbanization of aquatic systems - Degradation thresholds, stormwater detention and the limits of mitigations: Water Resources Bulletin, v. 33, p. 1077-1090.

Brown, L.R., Cuffney, T.F., Coles, J.F., Bell, A.H., May, J.T., Fitzpatrick, F., McMahon, G., and Steuer, J., 2009, Urban streams across the United States-Lessons learned from studies in 9 metropolitan areas: Journal of the North American Benthological Society, v. 28, no. 4, p. 1051-1069. doi: 10.1899/08-153.1.

Clarke, K.R., and Gorley, R.N., 2006, PRIMER version 6-User manual/Tutorial: Plymouth, United Kingdom, PRIMER-E Ltd.

Clausen, B., and Biggs, B.J.F., 2000, Flow variables for ecological studies in temperate streams - Groupings based on covariance: Journal of Hydrology, v. 237, p. 184-197. doi: 10.1016/S0022-1694(00)00306-1.

Cuffney, T.F., 2003, User's manual for the National WaterQuality Assessment Program Invertebrate Data Analysis System (IDAS) software-Version 3: U.S. Geological Survey Open-File Report 03-172, 114 p.

Cuffney, T.F., Bilger, M.D., and Brightbill, R.A., 2007, Ambiguous taxa-Effects on the characterization and interpretation of invertebrate assemblages: Journal of the North American Benthological Society, v. 26, p. 286-307.

Cuffney, T.F., Brightbill, R.A., May, J.T., and Waite, I.R., 2010, Responses of benthic macroinvertebrates to environmental changes associated with urbanization in nine metropolitan areas: Ecological Applications, v. 20, p. 1384-1401. doi: $10.1890 / 08-1311$.

Cuffney, T.F., and Falcone, J.F., 2008, Derivation of nationally consistent indices representing urban intensity within and across nine metropolitan areas of the conterminous United States: U.S. Geological Survey Scientific Investigations Report 2008-5095, 37 p.

DAYMET, 2005, Daily surface weather and climatological summaries: Missoula, Montana, Numerical Terradynamic Simulation Group, University of Montana, accessed December 20, 2011, at http://www.daymet.org.
Falcone, J., Stewart, J., Sobieszczyk, S., Dupree, J., McMahon, G., and Buell, G., 2007, A comparison of natural and urban characteristics and the development of urban intensity indices across six geographic settings: U.S. Geological Survey Scientific Investigations Report 2007-5123, 45 p.

Giddings, E.M.P., Bell, A.H., Beaulieu, K.M., Cuffney, T.F., Coles, J.F., Brown, L.R., Fitzpatrick, F.A., Falcone, J., Sprague, L.A., Bryant, W.L., Peppler, M.C., Stephens, C., and McMahon, G., 2009, Selected physical, chemical, and biological data used to study urbanizing streams in nine metropolitan areas of the United States, 1999-2004: U.S. Geological Survey Data Series 423, 11 p., plus data tables, accessed March 16, 2011, at http://pubs.usgs.gov/ds/423/.

Grimm, N.B., Foster, D., Groffman, P., Grove, J.M., Hopkinson, C.S., Nadelhoffer, K.J., Pataki, D.E., and Peters, D.P.C., 2008, The changing landscape-Ecosystem responses to urbanization and pollution across climatic and societal gradients: Frontiers in Ecology and the Environment, v. 6, p. 264-272.

Hirsch, R.M., 1982, A comparison of four streamflow record extension techniques: Water Resources Research, v. 18, p. 1081-1088. doi: 10.1029/WR018i004p01081.

Konrad, C.P., and Booth, D.B., 2002, Hydrologic trends resulting from urban development in a western Washington stream: U.S. Geological Survey Water-Resources Investigations Report 02-4040, $40 \mathrm{p}$.

Moulton, S.R., II, Carter, J.L., Grotheer, S.A., Cuffney, T.F., and Short, T.M., 2000, Methods for analysis by the U.S. Geological Survey National Water Quality LaboratoryProcessing, taxonomy, and quality control of benthic macroinvertebrate samples: U.S. Geological Survey Open-File Report 00-212, 49 p., accessed March 16, 2011, at http:// nwql.usgs.gov/Public/pubs/OFR00-212.html.

Moulton, S.R., II, Kennen, J.G., Goldstein, R.M., and Hambrook, J.A., 2002, Revised protocols for sampling algal, invertebrate, and fish communities as part of the National Water-Quality Assessment Program: U.S. Geological Survey Open-File Report 02-150, 75 p., accessed March 16, 2011, at http://water.usgs.gov/nawqa/protocols/OFR02-150/ index.html.

North Carolina Department of Environment and Natural Resources, 2006, Standard operating procedures for benthic macroinvertebrates: Biological Assessment Unit, Division of Water Quality, North Carolina Department of Environment and Natural Resources, Raleigh, North Carolina.

Olden, J.D., and Poff, N.L., 2003, Redundancy and the choice of hydrologic indices for characterizing streamflow regimes: River Research Applications, v. 19, p. 101-121. doi: 10.1002/rra.700. 
Omernik, J.M., 2000, Ecoregions of the United States (Omernik Level III): Washington, D.C., U.S. Environmental Protection Agency, accessed December 20, 2011, at http:// nationalatlas.gov/mld/forfrgi.html.

Paul, M.J., and Meyer, J.L., 2001, Streams in the urban landscape: Annual Review of Ecology and Systematics, v. 32, p. 333-365.

Quinn, J.M., and Hickey, C.W., 1994, Hydraulic parameters and benthic invertebrate distributions in two gravel-bed New Zealand rivers: Freshwater Biology, v. 32, no. 3, p. 489-500.

Richter, B.D., Baumgartner, J.V., Braun, D.P., Powell, J., and Braun, D.P., 1996, A method for assessing hydrologic alteration within ecosystems: Conservation Biology, v. 10, p. 1163-1174.

Robertson, A.L., Lancaster, J., Belyea, L.R., and Hildrew, A.G., 1997, Hydraulic habitat and the assemblage structure of stream benthic invertebrates: Journal of the North American Benthological Society, v. 16, p. 562-575.

Roy, A.H., Rosemond, A.D., Paul, M.J., Leigh, D.S., and Wallace, J.B., 2003, Stream macroinvertebrate response to catchment urbanisation (Georgia, U.S.A.): Freshwater Biology, v. 48, no. 2, p. 329-346.

SPSS, 2007, SYSTAT 12 Statistics I \& II: Chicago, Ill., SPSS, Inc.

Statzner, B., Gore, J.A., and Resh, V.H., 1988, Hydraulic stream ecology - Observed patterns and potential applications: Journal of the North American Benthological Society, v. 7 , p. $307-360$.
Steuer, J.J., Bales, J.D., and Giddings, E.M.P., 2009, Relationship of stream ecological conditions to simulated hydraulic metrics across a gradient of basin urbanization: Journal of the North American Benthological Society, v. 28, p. 955-976. doi: 10.1899/08-157.1.

Tate, C.M., Cuffney, T.F., McMahon, G., Giddings, E.M.P., and Zappia, H., 2005, Use of an urban intensity index to assess urban effects on streams in three contrasting environmental settings, in Brown, L.R., Gray, R.H., Hughes, R.M., and Meador, M.R., eds., Effects of urbanization on stream ecosystems: American Fisheries Society, Bethesda, Md., Symposium 47, p. 291-315.

Therneau, T.M., and Atkinson, B., 2010, rpart-Recursive Partitioning: R package version 3.1-46. Maintained by Ripley, B., at http://CRAN.R-project.org/package=rpart.

Trimble, S.W., 1974, Man-induced soil erosion on the Southern Piedmont, 1700-1970: Ankeny, Iowa: Soil Conservation Society of America.

Vieira, N.K.M., Poff, N.L., Carlisle, D.M., Moulton, S.R., II, Koski, M.L., and Kondratieff, B.C., 2006, A database of lotic invertebrate traits for North America: U.S. Geological Survey Data Series 187.Walsh, C.J., Roy, A.H., Feminella, J.W., Cottingham, P.D., Groffman, P.M., and Morgan, R.P., II, 2005, The urban stream syndrome-Current knowledge and the search for a cure: Journal of the American Benthological Society, v. 24, p. 706-723. 
Prepared by:

USGS Publishing Network

Raleigh Publishing Service Center

3916 Sunset Ridge Road

Raleigh, NC 27607

For additional information regarding this

publication, contact:

USGS Tennessee Water Science Center

640 Grassmere Park, Suite 100

Nashville, TN 37211

(615) $837-4700$

Or visit the USGS Tennessee Water Science

Center Web site at:

http://tn.water.usgs.gov 

通 